\title{
Inducing resistance in eggplant against Meloidogyne incognita by organic and inorganic fertilizers, plant growth regulators and amino acids
}

\author{
Ahmed A.Farahat*, Al-Sayed A. Al-Sayed*, Abedelmoneim M.Afify**and Nomer \\ M. Mahfoud* \\ ${ }^{*}$ Dept. of Zoology and Agric Nematology, ${ }^{* *}$ Dept.of Biochemistry \\ Fac. Of Agric, Cairo University
}

\begin{abstract}
Organic and inorganic fertilizers, commercial products containing organic and amino acids, vitamins as well as plant growth regulators were tested for their ability to induce nematode resistance in eggplant. Results indicated that organic fertilizers are significantly better than inorganic ones in reducing all the root-knot nematode counts with superiority to compost, Hyper $\mathrm{K}^{\circledast}$ and Union zinc ${ }^{\circledR}$ were the best inorganic fertilizers, although, they all could not reach the effect of vydate $10 \% \mathrm{G}$. All the tested commercial products containing organic and/or amino acids as well as plant growth regulators reduced significantly $M$. incognita counts. Indole acetic acid and indole butyric acid preceded all the tested materials in enhancing the resistance of eggplant against the root-knot nematode followed by ascorbic acid, amino zinc and citric acid. Results also proved that organic fertilizers (especially compost) were the best in improving plant growth. Other organic and inorganic materials significantly improved eggplant growth. Indole acetic acid, indole butyric acid, ascorbic acid, citric acid and amino zinc performed the best results.

Oxidant lipid peroxidase (MDA) was at the lowest values in roots of healthy plants and at the highest ones in the infected roots of untreated plants. Application of all the tested materials could preclude the formation of MDA. Only indole acetic acid, compost and indole butyric acid, in that order, brought the levels of MDA in infected roots to be near to that of the healthy plants without significant differences. The antioxidant enzymes SOD and APX increased in infected plants as a feed back to the increase in MDA. Also indole acetic acid, indole butyric acid and compost encouraged plants to produce levels of SOD and APX significantly higher than those of other treatments including healthy plants. The other tested materials heighten the levels of antioxidant enzymes to levels measured up the degree of nematode control they accomplished.
\end{abstract}

Key words: Resistance, Meloidogyne, Oxidant and antioxidant enzymes.

\section{Introduction}

Solanaceous plants are the most known susceptible plants to the root-knot nematodes, Meloidogyne spp. of which eggplant is the most common damaged by 
such nematodes. The root-knot nematode depend upon their development in their hosts on the formation of feeding sites e.g. giant cells. The success of nematode reproduction on compatible hosts depend on the successful formation of such feeding sites which rely on the availability of certain concentrations of some chemicals and enzymes (Baldacci-crespet al., 2012) to be available in host tissues. Consequently, any changes in such chemicals and/or enzymes due to pathogens or different stresses on the cultivated plants may affect the formation of such feeding sites.

In plants attacked by nematodes, selective changes occur in the metabolism either as consequence of the establishment of a susceptible host-pathogen interaction or as a result of resistance between host and parasite. Several models for resistance/susceptibility have been developed based on biochemical changes (Giebel, 1982 and Zacheoet al., 1987). There are many reports of enhanced peroxidases, polyphenoloxidase, and ascorbic acid oxidase following the interaction of nematodes with their hosts especially the resistant ones and this has led to the hypothesis that these enzymes may be important in the defense mechanism of the host (Saeed, 2005; Siahpoushet al., 2011, Aryalet al., 2011 and El-Belatagiet al., 2012).

Generally, incompatibility to nematodes expressed after infection and active mechanisms involved compounds produced post-infection rather than performed constitutive plant products (Kaplan and Keen, 1980). Accordingly, plants develop defense mechanisms right away after nematode invasion. Most of these defense mechanisms are incompatible resistant interactions between plants and pathogens of which the formation of reactive oxygen species (ROS) are common (Montes et al., 2004 and Bakker et al., 2006). Such reactive oxygen species induced lipid peroxidation accounting for cell death after pathogen invasion. Infected plants exhibit both enzymatic and non enzymatic antioxidant defense systems to frustrate ROS upon nematode infection. The accumulation of such materials in root tissues enhanced resistance in plants against invasion with new nematode larvae (EIBeltagiet al., 2012), of these antioxidants GSH, SOD, catalase and ascorbate oxidase. Such processexpress the so called systemic acquired resistance (SAR).

Systemic acquired resistance is the ability of plants to become resistant after prior infection by pathogens, exposure to stress, or application of chemical inducers (Sticheret al., 1997). An initial recognition event leads to the production of signals translocated endogenously to plant parts that are remote from the initial site of infection. The mechanism may have been the result of biochemical substances that were elicited in one side of the root system where incompatible reaction occurred and then expressed systematically (Chinnasriet al., 2006).

Many reports in literature illustrating the role of different materials and chemicals as systemic acquired resistance inducers in plants against nematode 
infection and reproduction. Of these, organic matter e.g. compost, organic manures of animal or plant origin (Farahat, et al., 2010), organic acids, e.g. salicylic, ascorbic, buteric, humic, folvic, citric (Saeed,2005 \&Kesba and El-Beltagi, 2012), amino acids (AmadulHoqueet al., 2013) and plant growth regulators (Farahat, 1989) are the most effective.

\section{Materials and methods}

\section{Stock cultures}

Pure stock culture of the root-knot nematode, Meloidogyne incognita originally obtained from galled eggplant roots was established. Single egg-masses from previously identified females (Taylor et al., 1955) were used to inoculate healthy eggplants grown in $20 \mathrm{~cm}$ clay pots filled with sterilized loamy sand soil. Two months after inoculation, plants were examined for nematode infection and reproduction. The culture was maintained on eggplant using infected roots with enough egg-masses for massive pure subcultures.

\section{Test plants}

Eggplant (Solanummelongena) hyb. Oneta F1 was used in the present study.

\section{Materials and doses}

Chicken manure, neem and eucalyptus leaves were collected from the Farm of the Faculty of Agriculture, Cairo University. Materials were air dried, ground and used at the rates of 5.0 or $10.0 \mathrm{~g} /$ plant. Commercial forms of the following materials were purchased from the Egyptian market and applied at the doses illustrated in Table(1).

\section{Green house experiment:}

Seedlings of eggplant hyb. Oneta F1 were inoculated with $4000 \mathrm{~J}_{2}$ of $M$. incognita. One week after nematode inoculation, the infected plants were treated with the organic, inorganic fertilizers, commercial formulations of amino and organic acids, vitamins and plant growth regulators with doses as illustrated in table (2). Each treatment was replicated 8 times and 8 inoculated plants were left without treatment as well as another 8 un-inoculated healthy plants to serve as check treatments. Pots were arranged in a complete randomized design on a clean bench in a greenhouse of $30^{\circ} \mathrm{C} \pm 2$ and horticulturally treated the same. Six weeks after nematode inoculation, plants were taken off and nematode counts in soil and on roots were enumerated. Plant growth criteria were recorded in four replicates. The plants of the other four replicates and both check treatments were sent to the laboratory for determination of the oxidant and antioxidant substances and enzyme activities. 
Table (1): Materials, doses/ concentrations and methods of application.

\begin{tabular}{|c|c|c|c|c|}
\hline Trade name & Company & Contents & Dose Plant & Method of application \\
\hline Mega power & $\begin{array}{l}\text { Union of Agricultural } \\
\text { Development (UAD) }\end{array}$ & $\begin{array}{l}\text { Humic acid } 19 \% \text {, folvic acid } 2 \% \text {, free amino acids } \\
5 \% \text {,chelated Znc } 0.5 \% \text {, chelated Fe } 0.025 \% \text {, } \\
\text { chelated Mn } 0.05 \% \text { and potassium } 2 \%\end{array}$ & $\begin{array}{l}1 \mathrm{ml} \\
2 \mathrm{mll}\end{array}$ & $\begin{array}{l}\text { Twioe with } 2 \text { weeks } \\
\text { interval, as foliar spray }\end{array}$ \\
\hline Nile compost & $\begin{array}{l}\text { Egyptian Company } \\
\text { for Solid Waste } \\
\text { Utilization (ECARU) }\end{array}$ & $\begin{array}{l}41-48 \% \text { organic matter, } 1.5-2 \% \text { nitrogen, } 0.8- \\
1.6 \% \text { potassium, } 24-28 \% \text { carbon, } 0.4-0.6 \% \\
\text { phosphorus, } 100 \text { ppm Fe, } 25-50 \mathrm{ppm} \mathrm{Zn}, 100-200 \\
\text { ppm Mn, } 20-25 \% \text { moisture, pH } 7.5-8.5, \mathrm{Ec} 3-4, \mathrm{C} / \mathrm{N} \\
\text { ratio } 1-14: 16 \text {. }\end{array}$ & $5 g, 10 \mathrm{~g} / \mathrm{pot}$ & $\begin{array}{l}\text { One week after infection, } \\
\text { as soil drench }\end{array}$ \\
\hline NAFK & $\begin{array}{l}\text { Union of Agriaultural } \\
\text { Development (UAD) }\end{array}$ & $\begin{array}{l}\text { Nitrogen } 19 \%, \text { Phosphorus 19\%, Potassium 19\% + } \\
\text { Mg,sulpher, Fe, Zn,Mn, Cu and Bo }\end{array}$ & $1.25,2.50 \mathrm{~g} / \mathrm{L}$ & $\begin{array}{l}\text { Twice with } 2 \text { weeks } \\
\text { interval, as foliar spray }\end{array}$ \\
\hline Union Fer & $\begin{array}{l}\text { Union of Agricultural } \\
\text { Development (UAD) }\end{array}$ & $6 \%$ chela ted iron by organic and amino acids. & $2 \mathrm{~g}, 4 \mathrm{~g} / \mathrm{L}$ & $\begin{array}{l}\text { One week after in ection, } \\
\text { as soil drench }\end{array}$ \\
\hline Union Manganese & $\begin{array}{l}\text { Union of Agricultural } \\
\text { Development (UAD) }\end{array}$ & $\begin{array}{l}13 \% \text { chelated manganese by organic and amino } \\
\text { acids }\end{array}$ & $2 \mathrm{~g} .4 \mathrm{~g} / \mathrm{L}$ & $\begin{array}{l}\text { One week after infection, } \\
\text { as soil drench }\end{array}$ \\
\hline Union Znc & $\begin{array}{l}\text { Union of Agriaultural } \\
\text { Development (UAD) }\end{array}$ & $12 \%$ chelated Zinc by organic and amino acids & $2 \mathrm{~g} .4 \mathrm{~g} / \mathrm{L}$ & $\begin{array}{l}\text { One week after in fection, } \\
\text { as soil drench }\end{array}$ \\
\hline Calsio-X & $\begin{array}{l}\text { Union of Agricultural } \\
\text { Development UAD }\end{array}$ & $\begin{array}{l}\text { Calcium } 9.8 \% \text {, nitrogen } 12 \% \text {, magnesium } 3.4 \%+ \\
\text { active humic and amino acids }\end{array}$ & $3 \mathrm{~g} .6 \mathrm{~g} / \mathrm{L}$ & $\begin{array}{l}\text { Twice with } 2 \text { weeks } \\
\text { interval, as foliar spray }\end{array}$ \\
\hline Hyper K & $\begin{array}{l}\text { Union of Agricultural } \\
\text { Development (UAD) }\end{array}$ & $60 \%$ potassium oxide & $2 \mathrm{~g} .4 \mathrm{~g} / \mathrm{L}$ & $\begin{array}{l}\text { Twice with } 2 \text { weeks } \\
\text { interval, as foliar spray }\end{array}$ \\
\hline NPK & $\begin{array}{l}\text { Grow Tech. for } \\
\text { industrial production }\end{array}$ & $19 / 19 / 19 \mathrm{NPK}$ & $1 \mathrm{~g} .2 \mathrm{~g} / \mathrm{L}$ & $\begin{array}{l}\text { One week after inection, } \\
\text { as soil drench }\end{array}$ \\
\hline Amino Power & $\begin{array}{l}\text { Union of Agricultural } \\
\text { Development (UAD) }\end{array}$ & $\begin{array}{l}\text { fee amino acids } 19 \% \text {, citric acid } 3 \% \text {, potassium } \\
3.5 \%, 1500 \text { ppm chela ted Fe, } 500 \text { ppm chelated zinc, } \\
500 \text { ppm chelated manganese }\end{array}$ & $0.5,1 \mathrm{~g} / \mathrm{L}$ & $\begin{array}{l}\text { One week after in ection, } \\
\text { as b liar spray }\end{array}$ \\
\hline Amino green & $\begin{array}{l}\text { Dishnr for Chemicals } \\
\text { - } \infty \text { mmerce - Egypt }\end{array}$ & $\begin{array}{l}15 \% \text { organic and amino acids, } 2.9 \% \mathrm{Fe}, 1.4 \% \text { Znc, } \\
0.7 \% \text { mang anese }\end{array}$ & $1 \mathrm{ml}, 2 \mathrm{mll}$ & $\begin{array}{l}\text { One week after in ection, } \\
\text { as foliar spray }\end{array}$ \\
\hline
\end{tabular}


Table (1): Cont'd

\begin{tabular}{|c|c|c|c|c|}
\hline Trade name & Company & Contents & Dose Plant & Method of application \\
\hline Amino Zne & $\begin{array}{l}\text { Dishnr for Chemicals } \\
\text { commerce - Egypt }\end{array}$ & $20 \%$ organic and amino acids $10 \%$ zinc & $1 \mathrm{ml}, 2 \mathrm{ml}$ & $\begin{array}{l}\text { One week after infection, } \\
\text { as bliar spray }\end{array}$ \\
\hline Amino manganese & $\begin{array}{l}\text { Dishnr for Chemicals } \\
\text { commerce - Egypt }\end{array}$ & $20 \%$ organic and amino acids, $10 \%$ manganese & $1 \mathrm{ml}, 2 \mathrm{~m} / \mathrm{L}$ & $\begin{array}{l}\text { One week after infection, } \\
\text { as bliar spray }\end{array}$ \\
\hline Amino Iron & $\begin{array}{l}\text { Dishnr for Chemicals } \\
\text { commerce - Egypt }\end{array}$ & $20 \%$ organic and amino acids, $8 \%$ iron & $1 \mathrm{ml}, 2 \mathrm{ml} / \mathrm{L}$ & $\begin{array}{l}\text { One week after infection, } \\
\text { as foliar spray }\end{array}$ \\
\hline Gutemic acid & $\begin{array}{l}\text { ROTH Bestellen Sie } \\
\text { Zum Null tarif Germany }\end{array}$ & aminoglutamic acid $99 \%\left[\mathrm{C}_{2} \mathrm{H}_{2} \mathrm{NO}_{4}\right]$ & $0.5 \mathrm{~g} .1 \mathrm{~g} / \mathrm{L}$ & $\begin{array}{l}\text { One week after inection, } \\
\text { as bliar spray }\end{array}$ \\
\hline Riboflavin & $\begin{array}{l}\text { ROTH Bestellen Sie } \\
\text { Zum Null tarif Germany }\end{array}$ & lactofavin, Vitamin $\mathrm{B} 2$, Vitemin $\mathrm{C}\left[\mathrm{C}_{17} \mathrm{H}_{20} \mathrm{~N}_{4} \mathrm{O}_{4}\right]$ & $0.5 \mathrm{~g}, 1 \mathrm{~g} / \mathrm{L}$ & $\begin{array}{l}\text { One week after infection, } \\
\text { as foliar spray }\end{array}$ \\
\hline Citric acid & $\begin{array}{l}\text { ROTH Bestellen Sie } \\
\text { Zum Null tarif Germany }\end{array}$ & Vitamin $\mathrm{C} 99 \%\left[\mathrm{C}_{\mathrm{a}} \mathrm{H}_{\mathrm{g}} \mathrm{O}_{\mathrm{a}}\right]$ & $0.5 \mathrm{~g}, 1 \mathrm{~g} / \mathrm{L}$ & $\begin{array}{l}\text { One week after inection, } \\
\text { as bliar spray }\end{array}$ \\
\hline UniBor & $\begin{array}{l}\text { Union of Agricultu ral } \\
\text { Develop ment (UAD) }\end{array}$ & $\begin{array}{l}\text { boron } 6 \% \text {, gibberellins } 0.05 \% \text {, vitamin B1 [thiamine, } \\
\text { ribofavin, nicotinic acid, pyidoxine, pyridoxal, } \\
\text { pyrodoxamine, biotin] }\end{array}$ & $0.75 \mathrm{~g}, 1.5 \mathrm{~g} / \mathrm{L}$ & $\begin{array}{l}\text { One week after infection, } \\
\text { as foliar spray }\end{array}$ \\
\hline Gibberellic acid $20 \%$ & $\begin{array}{l}\text { ROTH Bestellen Sie } \\
\text { Zum Null tarif Germany }\end{array}$ & $\mathrm{C}_{19} \mathrm{H}_{22} \mathrm{O}_{6}$ & $50,100 \mathrm{ppm}$ & $\begin{array}{l}\text { One week after in ection, } \\
\text { as bliar spray }\end{array}$ \\
\hline $\begin{array}{l}\text { Indole-3-acetic } \\
\text { acid } 98 \%\end{array}$ & $\begin{array}{l}\text { ROTH Bestellen Sie } \\
\text { Zum Null tarif Germany }\end{array}$ & $\mathrm{C}_{10} \mathrm{H}_{2} \mathrm{NO}_{2}$ & $50,100 \mathrm{ppm}$ & $\begin{array}{l}\text { One week after infection, } \\
\text { as foliar spray }\end{array}$ \\
\hline $\begin{array}{l}\text { Indole-3-butyric } \\
\text { acid } 98 \%\end{array}$ & $\begin{array}{l}\text { ROTH Bestellen Sie } \\
\text { Zum Null tarif Germany }\end{array}$ & $\mathrm{C}_{12} \mathrm{H}_{12} \mathrm{NO}_{2}$ & $50,100 \mathrm{ppm}$ & $\begin{array}{l}\text { One week after inection, } \\
\text { as fliar spray }\end{array}$ \\
\hline
\end{tabular}


Table (2): Treatments and doses / concentrations.

\begin{tabular}{|c|c|c|c|}
\hline Treatment & Dose/conc. & Treatment & Dose/conc. \\
\hline Mega power (Humic\&falvic) & $\begin{array}{l}1 \mathrm{ml} / \text { Liter } \\
2 \mathrm{ml} / \text { Liter }\end{array}$ & Amino power & $\begin{array}{l}0.5 \mathrm{ml} / \text { Liter } \\
1.0 \mathrm{ml} / \text { Liter }\end{array}$ \\
\hline Compost & $\begin{array}{l}5.0 \mathrm{~g} / \mathrm{pot} \\
10.0 \mathrm{~g} / \mathrm{pot}\end{array}$ & Amino green & $\begin{array}{l}1.0 \mathrm{ml} / \text { Liter } \\
2.0 \mathrm{ml} / \text { Liter }\end{array}$ \\
\hline Poultry manure & $\begin{array}{l}5.0 \mathrm{~g} / \mathrm{pot} \\
10.0 / \mathrm{pot}\end{array}$ & Amino Zinc & $\begin{array}{l}1.0 \mathrm{ml} / \text { Liter } \\
2.0 \mathrm{ml} / \text { Liter }\end{array}$ \\
\hline Eucalyptus dry leaves & $\begin{array}{l}\text { 5.0/pot } \\
10.0 \mathrm{~g} / \mathrm{pot}\end{array}$ & Amino manganese & $\begin{array}{l}1.0 \mathrm{ml} / \text { Liter } \\
2.0 \mathrm{ml} / \text { Liter }\end{array}$ \\
\hline Neem dry leaves & $\begin{array}{l}5.0 \mathrm{~g} / \mathrm{pot} \\
10.0 \mathrm{~g} / \mathrm{pot}\end{array}$ & Amino iron & $\begin{array}{l}1.0 \mathrm{ml} / \text { Liter } \\
2.0 \mathrm{ml} / \text { Liter }\end{array}$ \\
\hline Union Fer & $\begin{array}{l}2.0 \mathrm{~g} / \mathrm{Liter} \\
4.0 \mathrm{~g} / \mathrm{Liter}\end{array}$ & Glutamic acid & $\begin{array}{l}0.5 \mathrm{ml} / \text { Liter } \\
1.0 \mathrm{ml} / \text { Liter }\end{array}$ \\
\hline Union manganese & $\begin{array}{l}2.0 \mathrm{~g} / \mathrm{Liter} \\
4.0 \mathrm{~g} / \mathrm{Liter}\end{array}$ & Citric acid & $\begin{array}{l}0.5 \mathrm{ml} / \text { Liter } \\
1.0 \mathrm{ml} / \text { Liter }\end{array}$ \\
\hline Union Zinc & $\begin{array}{l}2.0 \mathrm{~g} / \mathrm{Liter} \\
4.0 \mathrm{~g} / \mathrm{Liter}\end{array}$ & Riboflavin & $\begin{array}{l}0.5 \mathrm{ml} / \text { Liter } \\
1.0 \mathrm{ml} / \text { Liter }\end{array}$ \\
\hline Calsio-X & $\begin{array}{l}1 \mathrm{ml} / \text { Liter } \\
2 \mathrm{ml} / \text { Liter }\end{array}$ & Ascorbic acid & $\begin{array}{l}0.5 \mathrm{ml} / \text { Liter } \\
1.0 \mathrm{ml} / \text { Liter }\end{array}$ \\
\hline Hyper-K & $\begin{array}{l}3.0 \mathrm{~g} / \mathrm{Liter} \\
6.0 \mathrm{~g} / \mathrm{Liter}\end{array}$ & UniBor & $\begin{array}{l}0.75 \mathrm{ml} / \text { Liter } \\
1.5 \mathrm{ml} / \text { Liter }\end{array}$ \\
\hline NPK & $\begin{array}{l}2.0 \mathrm{~g} / \mathrm{Liter} \\
4.0 \mathrm{~g} / \mathrm{Liter}\end{array}$ & Gibberellic acid & $\begin{array}{l}50 \text { ppm } \\
100 \text { ppm }\end{array}$ \\
\hline Ammonium nitrate & $\begin{array}{l}1.0 \mathrm{~g} / \text { / iter } \\
2.0 \mathrm{~g} / \mathrm{Liter}\end{array}$ & Indoleacetic acid & $\begin{array}{l}50 \text { ppm } \\
100 \text { ppm }\end{array}$ \\
\hline Vydate $10 \% \mathrm{G}$ & $\begin{array}{c}0.2 \mathrm{~g} / \mathrm{pot} \\
-\end{array}$ & Indole butyric acid & $\begin{array}{l}50 \text { ppm } \\
100 p p m\end{array}$ \\
\hline
\end{tabular}

\section{Nematode assay}

\section{a. Soil population}

Upon harvest, each pot was soaked in plastic bucket filled with water until the root system could be easily separated. Each root system was gently dried using soft clean tissue paper, weighed and stored in $5 \%$ formaldehyde in plastic jars. The soil suspension was quite stirred, then poured through a series of 60,200 and 325 mesh screens followed by Baermann set and collected after 48h. Hawksley counting slide was used to calculate the number of juveniles in one milliliter of suspension and then referred to the whole volume.

\section{b. Root population}

Roots were stained using acid fuchsine method (Goody, 1957). Five grams of the stain were added to one liter of distilled water, stirred and heated to boiling for about one minute. The root was then immersed in the stain for one minute, then removed and soaked in tap water to get rid of the excess stain. Developmental stages, mature females and egg-masses were counted under a stereo-microscope using two fine dissecting needles. 


\section{c. Eggs per egg-mass}

Ten egg-masses of uniform size were separated from the root, placed into a vial containing $20 \mathrm{ml}$ of sodium hypochlorite ( $\mathrm{NaOCL}, 0.5 \%$ ) and strongly shacked for 3 minutes. The suspension was then poured through a 500 mesh sieve, and the released eggs were gently washed with slow water stream of tap water to rinse off the residual $\mathrm{NaOCL}$. Eggs were then collected into $250 \mathrm{ml}$ beaker. An amount of 1 $\mathrm{ml}$ was withdrawn after the suspension was stirred well and dispensed onto a Hawksley counting slide, and examined under a compound microscope. The counted number was then referred to eggs per single egg-mass.

\section{Determination of oxidants and antioxidants:}

\section{a. Lipid peroxidation (MDA contents)}

Thiobarbituric acid reaction (TBA) as descrided by Heath and Packer (1968). The MDA equivalent was derived from the absorbance according to Hodges et al. (1999).

\section{b. Assay of SOD activity (SOD; EC 1.15.1.1)}

The activity of SOD was assayed by measuring its ability to inhibit the photochemical reduction of NBT using the method of Beauchamp and Fridovich (1971).

\section{Assay of ascorbate peroxidase (APX) activity (APOX; E.C. 1.11. 1. 11)}

Ascorbate peroxidase activity was estimated according to the method of Nakano and Asada (1981). Enzyme activity was determined by the decrease in absorbance of ascorbate at $290 \mathrm{~nm}$.

\section{Results}

Concerning the influence of organic and inorganic commercial fertilizers, data in table (3) indicate that organic materials are better than inorganic fertilizers in reducing all nematode counts in soil and on roots of eggplant (Hyb. Oneta F1) and varied significantly with those of the check and all the tested inorganic fertilizers. Compost achieved the best results in reducing the number of galls, developmental stages, egg-masses, females fecundity and, in consequence, the soil population, followed by neem dry leaves, poultry droppings and then eucalyptus dry leaves. Mega power (humic and folvic acids) was the least organic materials in reducing nematode counts. Hyper $\mathrm{K}$ followed by Union zinc were the best and varied significantly with the other tested inorganic fertilizers. NAFK, Union Fer, Union manganese, Calsio X, NPK and ammonium nitrate came statistically in the second category. Non of the tested materials could stand with Vydate $10 \% \mathrm{G}$ in reducing nematode counts. Except some cases, no significant differences were observed between the two doses tested in each treatment. 
Ahmed A. Farahat et al., .........

Table (3): Reproduction of $M$. incognita on eggplant as influenced by some organic and inorganic fer tilizers.

\begin{tabular}{|c|c|c|c|c|c|c|c|c|}
\hline \multirow{3}{*}{ Treatment } & \multirow{3}{*}{ Dose } & \multicolumn{7}{|c|}{ Nematode counts } \\
\hline & & \multicolumn{4}{|c|}{ Root Population } & \multirow{2}{*}{$\begin{array}{c}\text { Soil } \\
\text { population }\end{array}$} & \multirow{2}{*}{$\begin{array}{c}\text { Final } \\
\text { population }\end{array}$} & \multirow{2}{*}{$\begin{array}{l}\text { Eggs/ } \\
\text { eggmass }\end{array}$} \\
\hline & & Galls & D. 5 tages & Eggmasses & Total & & & \\
\hline \multirow{2}{*}{ Mega pover( (Humic \& falvic) } & $1 \mathrm{~m} U$ & $474 d-h$ & $142 \mathrm{bc}$ & 426 de & 568 & 1750 de & 2318 & $244 \mathrm{hi}$ \\
\hline & $2 \mathrm{ml}$ & 411 e-i & 123 ef & 389 ef & 512 & 1680 def & 2192 & $281 \mathrm{fg}$ \\
\hline Compost ${ }^{\omega}$ & $5 g$ & $227 \mathrm{k}$ & $91 \mathrm{j}$ & $145 i$ & 236 & $875 \mathrm{hi}$ & 1111 & $156 \mathrm{n}$ \\
\hline & $5 g$ & $316 \mathrm{~h}-1$ & $128 \mathrm{def}$ & $286 \mathrm{gh}$ & $\begin{array}{l}210 \\
412\end{array}$ & $1255 \mathrm{~g}$ & $\begin{array}{l}1030 \\
1087\end{array}$ & $\begin{array}{l}143 \circ \\
194 \mathrm{~m}\end{array}$ \\
\hline Poultry droppings & $\begin{array}{c}59 \\
10 g\end{array}$ & $293 \mathrm{ikl}$ & $86 \mathrm{j}$ & $244 \mathrm{hi}$ & 330 & $1195 \mathrm{gh}$ & $\begin{array}{l}1007 \\
1525\end{array}$ & $\begin{array}{l}194 \mathrm{~m} \\
189 \mathrm{~m}\end{array}$ \\
\hline Eucaluntus dry leaves & $5 g$ & $388 \mathrm{f}-\mathrm{k}$ & $137 \mathrm{bod}$ & $293 \mathrm{gh}$ & 430 & 1425 eg & 1855 & 2061 \\
\hline Eucalyptus dry le: & $10 \mathrm{~g}$ & $329 \mathrm{~g}-1$ & 96 i & 253 hi & 349 & 1380 fo & 1729 & $196 \mathrm{~lm}$ \\
\hline Neem dry leaves & $5 g$ & $308 \mathrm{i}-1$ & $94 \mathbf{j}$ & $268 \mathrm{gh}$ & 362 & $1230 \mathrm{gh}$ & 1592 & $186 \mathrm{~m}$ \\
\hline & $10 \mathrm{~g}$ & $286 \mathrm{jkl}$ & $88 \hat{\mathbf{j}}$ & $217 \mathrm{hi}$ & 305 & $1175 \mathrm{gh}$ & 1480 & $184 \mathrm{~m}$ \\
\hline NAFK@ & $\begin{array}{l}1.25 \mathrm{~g} \\
2.5 \mathrm{~g}\end{array}$ & 657 bc & $\begin{array}{l}132 \text { cde } \\
128 \text { def }\end{array}$ & $622 \mathrm{~b}$ & $\begin{array}{l}754 \\
691\end{array}$ & 2560 bc & 3314 & 278 de \\
\hline Union Fer@ & $2 g /$ & 569 bee & 119 é & 521 bod & 640 & 2565 bc & 3205 & 287 ef \\
\hline Union Fer $\mathbb{0}$ & $4 g /$ & 519 de & $101 \mathrm{hi}$ & 486 ode & 587 & $2230 \mathrm{c}$ & 2817 & 244 hi \\
\hline Union Mannanece $\AA$ & $2 g /$ & 563 b-e & 123 efg & $528 \mathrm{bcd}$ & 651 & $2430 \mathrm{bc}$ & 3081 & 288 ef \\
\hline & $4 g /$ & 516 cde & $112 \mathrm{gh}$ & 476 ode & 588 & $1985 \mathrm{~d}$ & 2573 & $251 \mathrm{gh}$ \\
\hline Union Zinc @ & $2 g /$ & $491 \mathrm{~d}-9$ & $94 \mathrm{j}$ & 487 ode & 581 & $1855 \mathrm{~d}$ & 2436 & $243 \mathrm{hi}$ \\
\hline & $4 g /$ & $483 \mathrm{~d}-\mathrm{g}$ & 95 j & 386 ef & 481 & $1820 \mathrm{~d}$ & 2301 & $220 \mathrm{k}$ \\
\hline Calsio X@ & $3 g /$ & $689 \mathrm{~b}$ & $138 \mathrm{bod}$ & $545 \mathrm{~b} d$ & 545 & 2485 bc & 3010 & $295 \mathrm{c}$ \\
\hline & $6 g /$ & 584 b-e & 113 gh & 532 bod & 645 & $2335 \mathrm{c}$ & 2980 & 288 ef \\
\hline Hyper K@ & $\begin{array}{l}2 g \text { d } \\
4 g h\end{array}$ & $\begin{array}{l}467 \mathrm{~d}-\mathrm{h} \\
421 \mathrm{e}-\mathrm{i}\end{array}$ & $\begin{array}{l}88 j \\
83 j\end{array}$ & $\begin{array}{l}429 \text { de } \\
376 \text { ef }\end{array}$ & $\begin{array}{l}515 \\
495\end{array}$ & $\begin{array}{c}1875 \mathrm{~d} \\
1620 \mathrm{def}\end{array}$ & $\begin{array}{l}2390 \\
2115\end{array}$ & $\begin{array}{l}236 \text { ij } \\
244 \mathrm{hi}\end{array}$ \\
\hline NPK@ & $19 /$ & $\begin{array}{l}689 \mathrm{~b} \\
683 \mathrm{~b}\end{array}$ & $\begin{array}{l}146 \mathrm{~b} \\
128 \mathrm{de}\end{array}$ & $\begin{array}{l}623 \mathrm{~b} \\
585 \mathrm{bc}\end{array}$ & $\begin{array}{l}769 \\
713\end{array}$ & $\begin{array}{l}2770 \mathrm{~b} \\
2585 \mathrm{bc}\end{array}$ & $\begin{array}{l}3539 \\
3298\end{array}$ & $\begin{array}{l}326 \mathrm{~b} \\
284 \mathrm{od}\end{array}$ \\
\hline Ammonium nitrte & $1 \mathrm{~g} /$ & $494 \mathrm{~d}-\mathrm{g}$ & $148 \mathrm{~b}$ & 534 bœd & 682 & $1955 \mathrm{~d}$ & 2637 & $253 \mathrm{~d}$ \\
\hline Ammonium nitrate & $2 g h$ & $485 \mathrm{~d}-9 \mathrm{~g}$ & 123 efg & 493 ode & 616 & $1765 \mathrm{de}$ & 2381 & 231 de \\
\hline Vydate $^{w} 10 \% G$ & $0.2 \mathrm{~g}$ & $47 \mathrm{~m}$ & $53 k$ & $21 \mathrm{j}$ & 74 & $460 j$ & 534 & $88 \mathrm{p}$ \\
\hline Check (infected) & & $1268 \mathrm{a}$ & $546 a$ & $1034 \mathrm{a}$ & 1580 & $4750 \mathrm{a}$ & 6330 & $424 \mathrm{a}$ \\
\hline
\end{tabular}


Regarding the organic, amino acids commercial products and plant growth regulators, data in table (4) signified that all the tested materials significantly reduced the nematode counts in soil and on eggplant roots. The plant growth regulators, indole acetic and indole butyric acids preceded all the tested materials in enhancing resistance in eggplant against the root-knot nematode performing the lowest numbers of all nematode counts. Ascorbic acid, amino zinc and citric acid were statistically ranked in the second category.

Respecting the growth response of eggplant to the tested materials, data in table (5) disclose that compost at both doses was the best among organic and inorganic materials in meliorating the growth of infected eggplant. Thus, it achieved the highest significant values of growth criteria and the highest rates of increase in plant length, plant fresh weight and shoot dry weight followed by poultry droppings and neem dry leaves without significant differences with those of the untreated healthy plants. Other organic and inorganic materials significantly improved the growth of eggplant over the infected untreated plants but failed to improve the growth of plants to stand with the untreated healthy ones. However, the plant growth regulators, indole acetic acid and butyric acid (Table 6) surpassed all the resistance inducing materials accomplishing the best results in improving plant growth criteria followed by ascorbic acid, citric acid and amino zinc.

On the subject of the response of eggplant to nematode infection and application of the tested materials, data in Figs (1 and 2) show that the activity of oxidant lipid peroxidase (MDA) was at the lowest value in the healthy plants and at the highest values in plants infected with the root-knot nematode and untreated with any of the tested materials followed by those treated with the nematicide without significant differences. All treatments, due to their action against the root-knot nematode, could preclude the formation of MDA in roots depending on the degree of nematode control. Only indole acetic acid, compost and indole butyric acid, in that order, brought the levels of MDA in infected roots nearly similar to that of the healthy plants without significant differences. The antioxidant enzymes, superoxide dismutase (SOD) and ascorbate peroxidase (APX) were increased in infected plants as a feed back to the increase in MDA (Figs.3-6). Materials that enhance nematode resistance like indole acetic acid, indole butyric acid and compost encouraged plants to produce levels of SOD and APX significantly higher than those of other treatments including healthy and infected untreated plants. The other tested materials heighten the levels of antioxidant enzymes to levels measured up the degree of nematode control they accomplished. The nematicide, Vydate, in spite it reduced nematode counts to the lowest significant levels, it was not of course of these materials that arose the antioxidant enzymes to high levels. 
Table (4): Reproduction of $M$. incogrita on eggplant as influenced by s ome res istance inducers and plant growth regulators.

\begin{tabular}{|c|c|c|c|c|c|c|c|c|}
\hline \multirow{3}{*}{ Treatment } & \multirow{3}{*}{ Dose } & \multicolumn{7}{|c|}{ Nema tode counts } \\
\hline & & \multicolumn{4}{|c|}{ Root Population } & \multirow{2}{*}{$\begin{array}{c}\text { Soil } \\
\text { Population }\end{array}$} & \multirow{2}{*}{$\begin{array}{c}\text { Final } \\
\text { population }\end{array}$} & \multirow{2}{*}{$\begin{array}{l}\text { Eggs/ } \\
\text { eggmass }\end{array}$} \\
\hline & & Galls & D. stages & Eggmasses & Total & & & \\
\hline Amino power @ & $0.5 \mathrm{~m} / /$ & $392 \mathrm{e}-\mathrm{i}$ & $78 \mathrm{k}$ & 397 of & 475 & $1935 q-k$ & 2410 & $213 h-k$ \\
\hline Amino power & $1 \mathrm{~m} U$ & 359 e-j & $79 \mathrm{k}$ & $3720-i$ & 451 & $1560 \mathrm{~h}-\mathrm{k}$ & 2011 & $189 \mathrm{i}-\mathrm{I}$ \\
\hline \multirow{2}{*}{ Amino green @ } & $1 \mathrm{mu}$ & $498 \mathrm{~d}-\mathrm{g}$ & 100 hij & 455 od & 555 & $2160 \mathrm{e}-\mathrm{h}$ & 2715 & $256 \mathrm{~d}-g$ \\
\hline & $2 \mathrm{mu}$ & $468 \mathrm{~d}-\mathrm{h}$ & $52 \mathrm{pq}$ & 432 cde & 484 & $1835 \mathrm{~g}-\mathrm{k}$ & 2319 & $233 \mathrm{gh}$ \\
\hline \multirow{2}{*}{ Aminozinc@ } & $1 \mathrm{~m} M$ & $343 \mathrm{f}-\mathrm{g}$ & $73 \mathrm{~lm}$ & $313 \mathrm{~d}-\mathrm{i}$ & 386 & $1335 \mathrm{i}-\mathrm{I}$ & 1721 & $194 \mathrm{i}$ \\
\hline & $2 \mathrm{mU}$ & $3129-j$ & 59 op & $296 d-i$ & 355 & $1070 \mathrm{i}-1$ & 1625 & $188 \mathrm{i}-\mathrm{I}$ \\
\hline \multirow{2}{*}{ Amino mangane se (} & $1 \mathrm{~m} M$ & $571 \mathrm{~d}$ & $134 \mathrm{e}$ & 486 od & 620 & 2850 def & 3470 & 264 o-f \\
\hline & $2 \mathrm{mU}$ & $487 \mathrm{~d}-\mathrm{g}$ & 97 ij & 436 ij & 533 & $2620 \mathrm{~d}-g$ & 3153 & $221 \mathrm{~g}-\mathrm{i}$ \\
\hline \multirow{2}{*}{ Amino iron $(1)$} & $1 \mathrm{mu}$ & 536 de & $107 \mathrm{gh}$ & 483 od & 590 & $2540 \mathrm{~d}-9$ & 3130 & $2640-f$ \\
\hline & $2 \mathrm{mU}$ & $472 d-h$ & $94 \mathrm{j}$ & 431 cde & 525 & $2325 \mathrm{~d}-\mathrm{h}$ & 2850 & $237 \mathrm{fgh}$ \\
\hline \multirow[t]{2}{*}{ Gluta mic acid } & $0.5 \mathrm{~A}$ & $\begin{array}{c}586 \mathrm{~d} \\
539 \mathrm{de}\end{array}$ & $117 \mathrm{f}$ & $541 \mathrm{c}$ & 658 & 2965 ode & 3623 & 289 od \\
\hline & $0.5 \mathrm{~A}$ & 375 e-j & $\begin{array}{c}108 \text { a } \\
95 \mathrm{j}\end{array}$ & 483 od & $\begin{array}{l}591 \\
475\end{array}$ & $2875 \mathrm{~d}-\mathrm{a}$ & 3268 & 276 ode \\
\hline \multirow{2}{*}{ Citric acid } & $1 \mathrm{~g} A$ & $329 \mathrm{~g}-\mathrm{j}$ & $68 \mathrm{mno}$ & 365 cil & $\begin{array}{l}4 / 5 \\
431\end{array}$ & $\begin{array}{l}1805 \mathrm{~g}-\mathrm{k} \\
1550 \mathrm{~h}-\mathrm{k}\end{array}$ & $\begin{array}{l}2340 \\
1981\end{array}$ & $\begin{array}{l}238 \mathrm{ghn} \\
220 \mathrm{~g}-\mathrm{j}\end{array}$ \\
\hline & $0.5 \mathrm{~A}$ & $759 \circ$ & $152 d$ & $828 \mathrm{~b}$ & 980 & $3150 \mathrm{bcd}$ & 4130 & $296 \mathrm{bc}$ \\
\hline Riboflavin & $1 \mathrm{~g} A$ & $487 \mathrm{~d}-9$ & $77 \mathrm{k}$ & 467 od & 544 & $2320 \mathrm{~d}-\mathrm{h}$ & 2884 & 203 ijk \\
\hline \multirow{2}{*}{ Ascorbic acid } & $0.5 \mathrm{~A}$ & $336 \mathrm{g-j}$ & $68 \mathrm{mn}$ & $295 \mathrm{~d}-\mathrm{i}$ & 363 & $1195 \mathrm{j}-\mathrm{m}$ & 1558 & $186 \mathrm{jkl}$ \\
\hline & 1 g्र $A$ & 311 Q -1 & 62 no & 262 e-i & 324 & $1060 \mathrm{klm}$ & 1384 & $182 \mathrm{kl}$ \\
\hline \multirow[t]{2}{*}{ Uni boron $₫$} & $0.75 \mathrm{~m} / /$ & $434 \mathrm{~d}-\mathrm{i}$ & 104 ghi & 411 ode & 515 & $1985 \mathrm{f}-\mathrm{i}$ & 2500 & $263 c-f$ \\
\hline & $1.5 \mathrm{~m} / /$ & 387 e-i & 72 lm & 395 of & 467 & $1625 \mathrm{~h}-\mathrm{k}$ & 2092 & $245 \mathrm{e}-\mathrm{h}$ \\
\hline \multirow[t]{2}{*}{ Gibberellic acid } & $50 \mathrm{ppm}$ & $989 \mathrm{~b}$ & $232 \mathrm{c}$ & $876 a b$ & 1108 & 3750 bc & 4858 & $322 \mathrm{~b}$ \\
\hline & $\begin{array}{l}100 \mathrm{ppm} \\
50 \mathrm{pom}\end{array}$ & $\begin{array}{l}1014 \mathrm{~b} \\
203 \mathrm{ikl}\end{array}$ & $\begin{array}{c}246 \mathrm{~b} \\
46 \mathrm{~g}\end{array}$ & $\begin{array}{l}893 \mathrm{a} \\
190 \mathrm{ik}\end{array}$ & $\begin{array}{c}1139 \\
238\end{array}$ & $3955 \mathrm{~b}$ & $\begin{array}{l}5094 \\
1028\end{array}$ & 395 a \\
\hline Indole acetic acid & $100 \mathrm{ppm}$ & $182 \mathrm{kl}$ & $36 \mathrm{r}$ & $156 \mathrm{jk}$ & $\begin{array}{l}230 \\
192\end{array}$ & $765 \mathrm{~lm}$ & $\begin{array}{l}1020 \\
957\end{array}$ & $140 \mathrm{~m}$ \\
\hline Indol e butyric acid & $50 \mathrm{ppm}$ & $278 \mathrm{~h}-\mathrm{k}$ & $83 k$ & 211 & 294 & $875 \mathrm{~lm}$ & 1169 & $172 \mathrm{~lm}$ \\
\hline Yudate 10240 & 100 ppm & 242 ijk & $48 \mathrm{q}$ & 190 ijk & 238 & $855 \mathrm{~lm}$ & 1093 & $156 \mathrm{~lm}$ \\
\hline $\begin{array}{l}\text { Vydate } 10 \% \mathrm{G} \\
\text { Check (infected) }\end{array}$ & $02 \mathrm{~g}$ & $\begin{array}{c}47 i \\
1286 \mathrm{a}\end{array}$ & $\begin{array}{l}53 \mathrm{pq} \\
546 \mathrm{a}\end{array}$ & $\begin{array}{l}21 \mathrm{k} \\
1034^{\mathrm{a}}\end{array}$ & $\begin{array}{c}74 \\
1580\end{array}$ & $\begin{array}{l}460 \mathrm{~m} \\
4750 \mathrm{a}\end{array}$ & $\begin{array}{c}534 \\
6330\end{array}$ & $\begin{array}{l}88 \mathrm{n} \\
424 \mathrm{a}\end{array}$ \\
\hline
\end{tabular}

-Valves folowed by the same leter( $(8)$ are not slgilicantly offerent $(p=0.5)$. 
Table (5): Growth of eggplant infected with $M$. incognita as influenced by organic and inorganic fertilizers

\begin{tabular}{|c|c|c|c|c|c|c|c|c|c|c|c|}
\hline \multirow{3}{*}{ Tre atment } & \multirow{3}{*}{ Dose } & \multicolumn{10}{|c|}{ Growth criteria } \\
\hline & & \multicolumn{4}{|c|}{ Fresh we ight (g) } & \multicolumn{4}{|c|}{ Length $(\mathrm{cm})$} & \multicolumn{2}{|c|}{ Shoot dry weight } \\
\hline & & Shoot & Root & Total & \% change & Shoot & Root & total & $\%$ change & Weight & $\%$ change \\
\hline $\begin{array}{l}\text { Mega power@ } \\
\text { (Humic \& falvic) }\end{array}$ & $\begin{array}{l}1 \mathrm{mU} \\
2 \mathrm{ml}\end{array}$ & $\begin{array}{c}5.0 \mathrm{ij} \\
6.2 \mathrm{fgh}\end{array}$ & $\begin{array}{l}2.9 \mathrm{~g}-\mathrm{j} \\
3.2 \mathrm{e}-\mathrm{i}\end{array}$ & $\begin{array}{l}7.9 \\
9.4\end{array}$ & $\begin{array}{l}54.9 \\
84.3\end{array}$ & $\begin{array}{l}23.5 \mathrm{~g}-\mathrm{j} \\
25.8 \mathrm{~d}-\mathrm{h}\end{array}$ & $\begin{array}{l}15.0 \text { a-e } \\
16.5 \text { a-d }\end{array}$ & $\begin{array}{l}38.5 \\
42.3\end{array}$ & $\begin{array}{l}71.1 \\
88.0\end{array}$ & $\begin{array}{l}0.5 \mathrm{~g}-\mathrm{j} \\
0.8 \mathrm{~d}-\mathrm{g}\end{array}$ & $\begin{array}{c}66.7 \\
168.7\end{array}$ \\
\hline Compost" & $\begin{array}{c}5 g \\
10 g\end{array}$ & $\begin{array}{l}11.2 \mathrm{~b} \\
12.4 \mathrm{a}\end{array}$ & $\begin{array}{c}4.5 \mathrm{ab} \\
4.8 \mathrm{a}\end{array}$ & $\begin{array}{l}15.7 \\
17.2\end{array}$ & $\begin{array}{l}207.8 \\
237.3\end{array}$ & $\begin{array}{l}32.8 \mathrm{ab} \\
35.0 \mathrm{a}\end{array}$ & $\begin{array}{c}18.5 \mathrm{ab} \\
19.0 \mathrm{a}\end{array}$ & $\begin{array}{l}51.3 \\
54.0\end{array}$ & $\begin{array}{l}128.0 \\
140.0\end{array}$ & $\begin{array}{c}1.2 \mathrm{ad} \\
1.5 \mathrm{a}\end{array}$ & $\begin{array}{l}300.0 \\
400.0\end{array}$ \\
\hline Poultry droppings & $5 g$ & $9.0 \mathrm{~d}$ & 3.5 of & 12.5 & 145.1 & 29.5 a-f & $16.5 \mathrm{a}-\mathrm{d}$ & 46.0 & 104.4 & 1.1 ae & 268.7 \\
\hline Pourty aroppings & $10 \mathrm{~g}$ & 9.5 od & $3.9 \mathrm{~b}=$ & 13.4 & 162.7 & 31.0 a-d & 17.0 a-d & 48.0 & 113.3 & $1.2 \mathrm{add}$ & 300.0 \\
\hline Eucalyptus dry & $5 g$ & $6.3 \mathrm{fg}$ & $3.1 \mathrm{e}-\mathrm{j}$ & 9.4 & 84.3 & $26.5 \mathrm{\circ g}$ & 14.5 are & 41.0 & 822 & $0.9 \circ f$ & 200.0 \\
\hline leaves & $10 a$ & $7.3 \mathrm{e}$ & $3.5 \circ f$ & 10.8 & 111.8 & 27.5 b-a & 17.0 a-d & 44.5 & 97.8 & $1.0 \mathrm{~b}=$ & 233.3 \\
\hline Neem dry le aves & $5 g$ & 9.3 od & 3.8 bee & 13.1 & 156.9 & 30.0 a-e & $17.5 \mathrm{abc}$ & 47.5 & 111.1 & 1.1 ae & 268.7 \\
\hline & $\begin{array}{l}109 \\
1250\end{array}$ & $2.9 \mathrm{mno}$ & 4.2 abc & $\begin{array}{c}14.1 \\
5.5\end{array}$ & $\begin{array}{c}176.5 \\
78\end{array}$ & $32.0 \mathrm{abc}$ & $18.2 \mathrm{abc}$ & 50.2 & 123.1 & $1.3 \mathrm{abc}$ & 333.3 \\
\hline NAFK ${ }^{W}$ & $\begin{array}{l}1.25 \mathrm{~g} \\
2.5 \mathrm{~g}\end{array}$ & $\begin{array}{c}2.9 \mathrm{mno} \\
32 \mathrm{ko}\end{array}$ & $\begin{array}{l}2.6 \mathrm{hij} \\
2.7 \mathrm{g-j}\end{array}$ & $\begin{array}{l}5.5 \\
5.9\end{array}$ & $\begin{array}{c}7.8 \\
15.7\end{array}$ & $\begin{array}{l}18.8 \mathrm{jkl} \\
20.5 \mathrm{i}-\mathrm{l}\end{array}$ & $\begin{array}{l}13.5 \text { a-e } \\
13.8 \text { a-e }\end{array}$ & $\begin{array}{l}32.3 \\
34.3\end{array}$ & $\begin{array}{l}43.6 \\
52.4\end{array}$ & $\begin{array}{l}0.3 \mathrm{ij} \\
0.3 \mathrm{ii}\end{array}$ & $\begin{array}{l}0.0 \\
0.0\end{array}$ \\
\hline Union Fer ${ }^{*}$ & $2 g i$ & $4.0 \mathrm{kl}$ & $2.9 \mathrm{g-j}$ & 6.9 & 35.3 & $22.8 \mathrm{~h}-\mathrm{k}$ & 13.3 bee & 36.1 & 60.4 & 0.4 hij & 33.3 \\
\hline Union rer & 49 & 5.3 hij & $3.1 \mathrm{ej}$ & 8.4 & 64.7 & $24.5 \mathrm{e}-\mathrm{i}$ & 15.2 a-d & 39.7 & 76.4 & $0.6 \mathrm{f}-\mathrm{i}$ & 100.0 \\
\hline Union Manganese" & $2 g \mathrm{~g}$ & $\begin{array}{l}4.6 \mathrm{jk} \\
5.8 \mathrm{ghi}\end{array}$ & $\begin{array}{l}3.0 \mathrm{foj} \\
3.1 \mathrm{e}-\mathrm{j}\end{array}$ & $\begin{array}{l}7.6 \\
8.9\end{array}$ & $\begin{array}{l}49.0 \\
74.5\end{array}$ & $\begin{array}{l}23.8 \mathrm{~g}-\mathrm{j} \\
24.5 \mathrm{e}-\mathrm{j}\end{array}$ & $\begin{array}{l}15.2 \mathrm{a} \text { a-d } \\
16.6 \mathrm{a}-\mathrm{d}\end{array}$ & $\begin{array}{l}39.0 \\
41.1\end{array}$ & $\begin{array}{l}73.3 \\
82.7\end{array}$ & $\begin{array}{l}0.5 \mathrm{~g}-\mathrm{j} \\
0.7 \mathrm{e}-\mathrm{h}\end{array}$ & $\begin{array}{c}66.7 \\
133.3\end{array}$ \\
\hline Union Zinc " & $2 g /$ & 5.6 ghi & $3.2 \mathrm{e}-\mathrm{i}$ & 8.8 & 72.5 & $24.2 \mathrm{fj}$ & 15.5 a-d & 39.7 & 76.4 & $0.6 \mathrm{f}-\mathrm{i}$ & 100.0 \\
\hline & 49 & $6.2 \mathrm{fgh}$ & $3.40-9$ & 9.6 & 88.2 & $25.8 \mathrm{~d}-\mathrm{h}$ & $16.6 \mathrm{ard}$ & 42.4 & 90.7 & $0.7 \mathrm{eh}$ & 133.3 \\
\hline Calsio X & $3 g /$ & $3.5 \mathrm{lmn}$ & 2.6 hij & 6.1 & 19.6 & $22.0 \mathrm{~h}-\mathrm{k}$ & 13.2 de & 35.2 & 56.4 & 0.3 ij & 0.0 \\
\hline & $6 \mathrm{~g} /$ & $3.8 \mathrm{kl}$ & $2.9 \mathrm{g-j}$ & 6.7 & 31.4 & $22.5 \mathrm{~h}-\mathrm{k}$ & 14.5 a-e & 37.0 & 64.4 & 0.4 hij & 33.3 \\
\hline Hyper K@ & $2 g \|$ & $6.1 \mathrm{fgh}$ & $3.5 \circ f$ & 9.6 & 88.2 & $25.5 \mathrm{~d}-\mathrm{h}$ & $16.2 \mathrm{a}-\mathrm{d}$ & 38.7 & 72.0 & $0.8 \mathrm{~d}-g$ & 166.7 \\
\hline & 401 & 6.8 ef & $3.9 \mathrm{~b}-\mathrm{e}$ & 10.7 & 109.8 & $26.7 \mathrm{c}-9$ & 16.8 a-d & 43.5 & 93.3 & $0.9 \circ f$ & 200.0 \\
\hline NPK@ & $\begin{array}{l}1 g / 1 \\
2 g /\end{array}$ & $\begin{array}{l}2.60 \\
3.9 \mathrm{kl}\end{array}$ & $\begin{array}{l}2.5 \mathrm{jk} \\
2.8 \mathrm{~g}-\mathrm{j}\end{array}$ & $\begin{array}{l}5.1 \\
6.7\end{array}$ & $\begin{array}{c}0.0 \\
31.4\end{array}$ & $\begin{array}{l}17.5 \mathrm{klm} \\
21.5 \mathrm{~h}-\mathrm{l}\end{array}$ & $\begin{array}{l}12.2 \text { de } \\
13.9 \mathrm{a}-\mathrm{e}\end{array}$ & $\begin{array}{l}29.7 \\
35.4\end{array}$ & $\begin{array}{l}32.0 \\
57.3\end{array}$ & $\begin{array}{l}0.3 \text { ij } \\
0.4 \text { hii }\end{array}$ & $\begin{array}{c}0.0 \\
33.3\end{array}$ \\
\hline Ammonium nitrate & $1 g /$ & $5.7 \mathrm{ghi}$ & $3.1 \mathrm{e}-\mathrm{j}$ & 8.8 & 72.5 & $24.5 \mathrm{e}-\mathrm{i}$ & 15.8 a-d & 40.3 & 79.1 & $0.7 \mathrm{eh}$ & 133.3 \\
\hline Ring & & 6.1 figh & $3.3 \mathrm{~d}-\mathrm{h}$ & 9.4 & 84.3 & $25.5 \mathrm{~d}-\mathrm{h}$ & $16.5 \mathrm{a}-\mathrm{d}$ & 42.0 & 86.7 & $0.8 \mathrm{~d}-g$ & 166.7 \\
\hline Vydate $10 \% G$ & $0.2 \mathrm{~g}$ & $3.7 \mathrm{~m}$ & $2.3 \mathrm{jk}$ & 6.0 & 17.6 & $16.5 \mathrm{~lm}$ & $14.0 \mathrm{a}-\mathrm{e}$ & 30.5 & 35.6 & $0.3 \mathrm{ij}$ & 0.0 \\
\hline Check(infected) & & 2.7 no & $2.4 \mathrm{k}$ & 5.1 & & $12.5 \mathrm{~m}$ & $10.0 \mathrm{e}$ & 22.5 & & $0.3 \mathrm{ij}$ & \\
\hline Check(Healthy) & & $10.1 \mathrm{c}$ & $4.1 \mathrm{a}-\mathrm{d}$ & 14.2 & 178.4 & $30.5 \mathrm{a}-\mathrm{e}$ & $18.2 \mathrm{abc}$ & 48.7 & 116.4 & $1.4 \mathrm{ab}$ & 368.7 \\
\hline
\end{tabular}


Table (6): Growth of eggplant infected with $M$. incognita as influenced by some res istance inducers and plant growth regulators .

\begin{tabular}{|c|c|c|c|c|c|c|c|c|c|c|c|}
\hline \multirow{3}{*}{ Treatment } & \multirow{3}{*}{ Dose } & \multicolumn{10}{|c|}{ Growth criteria } \\
\hline & & \multicolumn{4}{|c|}{ Fresh weight (g) } & \multicolumn{4}{|c|}{ Length $(\mathrm{cm})$} & \multicolumn{2}{|c|}{ Shoot dry weight } \\
\hline & & Shoot & Root & Total & \% change & Shoot & Root & Total & \% change & Weight & \% change \\
\hline A mino power" & $\begin{array}{c}0.5 \mathrm{mU} \\
1 \mathrm{~m} / 1\end{array}$ & $\begin{array}{l}6.5 \mathrm{hi} \\
6.9 \mathrm{gh}\end{array}$ & $\begin{array}{c}3.5 \text { ef } \\
3.8 \text { dede }\end{array}$ & $\begin{array}{l}10.0 \\
10.7\end{array}$ & $\begin{array}{c}96.1 \\
109.8\end{array}$ & $\begin{array}{l}27.5 \text { ghi } \\
27.8 \mathrm{fij}\end{array}$ & $\begin{array}{c}15.8 \mathrm{i} \\
17.2 \mathrm{fh}\end{array}$ & $\begin{array}{l}43.3 \\
45.0\end{array}$ & $\begin{array}{c}92.4 \\
100.0\end{array}$ & $\begin{array}{l}0.8 \text { ef } \\
1.0 \text { ode }\end{array}$ & $\begin{array}{l}188.7 \\
233.3\end{array}$ \\
\hline & $1 \mathrm{~m} / /$ & $4.7 \mathrm{lmn}$ & $2.8 \mathrm{gh}$ & 7.5 & 47.1 & $22.5 \mathrm{lmn}$ & $13.5 \mathrm{mn}$ & 36.0 & 60.0 & $0.5 \mathrm{ghi}$ & 66.7 \\
\hline A mino green & $2 \mathrm{mU}$ & $4.9 k-n$ & $2.9 \mathrm{~g}$ & 7.8 & 52.9 & $24.2 \mathrm{jkl}$ & $14.3 \mathrm{j}-\mathrm{m}$ & 38.5 & 71.1 & $0.6 \mathrm{f}-\mathrm{i}$ & 100.0 \\
\hline A mino zinc ${ }^{w}$ & $1 \mathrm{~m} M$ & $7.5 \mathrm{~g}$ & 3.9 be & 11.4 & 123.5 & $29.3 \mathrm{~d}-\mathrm{h}$ & $17.0 \mathrm{gh}$ & 46.3 & 105.8 & 1.0 ode & 233.3 \\
\hline & $2 \mathrm{ml}$ & $8.9 \mathrm{e}$ & $4.1 \mathrm{bod}$ & 13.0 & 154.9 & $30.0 \mathrm{~d}-\mathrm{g}$ & $17.5 \mathrm{e}-\mathrm{h}$ & 47.5 & 111.1 & $1.1 \mathrm{~b}-\mathrm{e}$ & 266.7 \\
\hline A mino manganese ${ }^{w}$ & $1 \mathrm{~m} U$ & $4.61-0$ & $2.7 \mathrm{ghi}$ & 7.3 & 43.1 & $22.5 \mathrm{lmn}$ & $14.0 \mathrm{k}-\mathrm{n}$ & 36.5 & 62.2 & $0.5 \mathrm{ghi}$ & 66.7 \\
\hline & $2 \mathrm{mU}$ & $5.1 \mathrm{klm}$ & 2.9 व & 8.0 & 56.9 & $24.2 \mathrm{ikl}$ & $14.5 \mathrm{ik}$ & 38.6 & 71.6 & $0.6 \mathrm{f}-\mathrm{i}$ & 100.0 \\
\hline A mino iron ${ }^{*}$ & $1 \mathrm{mu}$ & $5.0 \mathrm{klm}$ & $2.9 \mathrm{~g}$ & 7.9 & 54.9 & $23.4 \mathrm{~km}$ & $142 \mathrm{~km}$ & 37.6 & 67.1 & 0.5 ghi & 68.7 \\
\hline & $2 \mathrm{ml} /$ & $\begin{array}{l}5.8 \mathrm{ljk} \\
4.2 \mathrm{~m}=0\end{array}$ & $3.1 \mathrm{fg}$ & 8.9 & $\begin{array}{l}74.5 \\
35.3\end{array}$ & $25.5 \mathrm{ijk}$ & $14.9 \mathrm{ijk}$ & 40.4 & 79.6 & $0.7 \mathrm{e}-\mathrm{h}$ & 133.3 \\
\hline Glutamic acid & $\begin{array}{l}0.5 \pi \\
1.9 /\end{array}$ & $\begin{array}{l}4.2 \mathrm{~m}-\mathrm{p} \\
4.5 \mathrm{~m}-\mathrm{p}\end{array}$ & $\begin{array}{l}2.7 \mathrm{ghi} \\
2.8 \mathrm{gh}\end{array}$ & $\begin{array}{l}6.9 \\
7.3\end{array}$ & $\begin{array}{l}35.3 \\
43.1\end{array}$ & $\begin{array}{l}20.8 \mathrm{mn} \\
22.6 \mathrm{Imn}\end{array}$ & $\begin{array}{l}132 . \mathrm{no} \\
13.5 \mathrm{mo}\end{array}$ & $\begin{array}{l}34.0 \\
38.1\end{array}$ & $\begin{array}{l}51.1 \\
60.4\end{array}$ & $\begin{array}{l}0.4 \mathrm{hl} \\
0.4 \mathrm{hi}\end{array}$ & $\begin{array}{l}33.3 \\
333\end{array}$ \\
\hline & $0.5 /$ & 7.56 & 3.8 cde & 11.3 & 121.6 & $28.0 \mathrm{e}-\mathrm{i}$ & $17.1 \mathrm{gh}$ & 45.1 & 100.4 & 1.0 cde & 233.3 \\
\hline Citric acid & $1 \mathrm{~g} /$ & $8.0 \mathrm{f}$ & $3.9 \mathrm{~b}=$ & 11.9 & 133.3 & $29.3 \mathrm{~d}-\mathrm{h}$ & $17.8 \mathrm{~d}-\mathrm{g}$ & 47.1 & 1093 & 0.9 def & 200.0 \\
\hline Rihofl-nim & $0.5 /$ & $3.6 \mathrm{op}$ & $2.4 \mathrm{hi}$ & 6.0 & 17.6 & $20.0 \mathrm{n}$ & 12.50 & 32.5 & 44.4 & $0.3 \mathrm{i}$ & 00.0 \\
\hline Riborlavin & $1 \mathrm{~g} / \mathrm{I}$ & $4.0 \mathrm{op}$ & 3.1 fg & 7.1 & 39.2 & $21.5 \mathrm{mn}$ & $13.6 \mathrm{lmn}$ & 35.1 & 56.0 & $0.4 \mathrm{hi}$ & 33.3 \\
\hline A scorbic acid & $0.5 / 1$ & $9.8 \propto$ & $4.0 \mathrm{bœd}$ & 13.8 & 170.6 & $30.8 \mathrm{~d}$ & $17.8 \mathrm{~d}-\mathrm{g}$ & 48.6 & 116.0 & $1.2 \mathrm{bcd}$ & 300.0 \\
\hline A scorbic acid & & $10.3 \mathrm{c}$ & $4.3 \mathrm{~b}$ & 14.6 & 186.3 & $31.1 \propto$ & $18.5 \mathrm{bod}$ & 49.6 & 120.4 & $1.3 \mathrm{bc}$ & 333.3 \\
\hline Uni b & $0.75 \mathrm{ml} /$ & $5.5 \mathrm{jkl}$ & 3.5 ef & 9.0 & 76.5 & $25.8 \mathrm{ijk}$ & 152 ij & 41.0 & 82.2 & $0.6 \mathrm{f}-\mathrm{i}$ & 100.0 \\
\hline Uni boron & $1.5 \mathrm{ml}$ & $6.3 \mathrm{hij}$ & $3.7 \mathrm{de}$ & 10.0 & 96.1 & $27.2 \mathrm{hi}$ & $16.8 \mathrm{~h}$ & 44.0 & 95.6 & 0.8 efg & 168.7 \\
\hline Gibberellic acid & $50 \mathrm{ppm}$ & 5.5 hij & $3.8 \mathrm{cde}$ & 9.3 & 82.4 & 302 def & $17.5 \mathrm{e}-\mathrm{h}$ & 47.7 & 112.0 & $0.6 \mathrm{f}-\mathrm{i}$ & 100.0 \\
\hline & $100 \mathrm{ppm}$ & $6.3 \mathrm{ikl}$ & $3.9 \mathrm{~b}=$ & 10.2 & 100.0 & $31.5 \propto$ & $18.8 \mathrm{bc}$ & 50.3 & 123.6 & 0.8 etg & 166.7 \\
\hline Indole acetic acid & $50 \mathrm{ppm}$ & $11.6 \mathrm{~b}$ & 4.9 a & 16.5 & 223.5 & $33.8 \mathrm{~b}$ & $19.1 \mathrm{~b}$ & 52.9 & 135.1 & $1.3 \mathrm{bc}$ & 333.3 \\
\hline & $50 \mathrm{pom}$ & $12.9 \mathrm{a}$ & $5.1 \mathbf{a}$ & 18.0 & 252.9 & $36.5 \mathrm{a}$ & $20.5 \mathrm{a}$ & 57.0 & 153.3 & $1.8 \mathrm{a}$ & 500.0 \\
\hline Indole butyric acid & $\begin{array}{l}50 \mathrm{ppm} \\
100 \mathrm{pm}\end{array}$ & 9.2 de & $4.0 \mathrm{bod}$ & 13.2 & 158.8 & $31.0 \propto d$ & $18.1 \mathrm{o}-\mathrm{f}$ & 49.1 & 118.2 & $1.1 \mathrm{~b}-\mathrm{e}$ & 286.7 \\
\hline Vydate $^{w} 10 \%$ G & $\begin{array}{l}100 \mathrm{ppm} \\
0.2 \mathrm{~g}\end{array}$ & $\begin{array}{l}9.5 \text { cole } \\
3.7 \text { op }\end{array}$ & $\begin{array}{l}4.2 \mathrm{bc} \\
2.3 \mathrm{hi}\end{array}$ & $\begin{array}{c}13.7 \\
6.0\end{array}$ & $\begin{array}{c}168.6 \\
17.6\end{array}$ & $\begin{array}{l}33.5 \mathrm{bc} \\
16.5 \mathrm{no}\end{array}$ & $\begin{array}{l}18.8 \mathrm{bc} \\
14.0 \mathrm{k}-n\end{array}$ & $\begin{array}{l}52.3 \\
30.5\end{array}$ & $\begin{array}{l}132.4 \\
35.6\end{array}$ & $\begin{array}{c}1.2 \mathrm{bcd} \\
0.3 \mathrm{i}\end{array}$ & $\begin{array}{c}300.0 \\
00.0\end{array}$ \\
\hline & & $2.7 \mathrm{~g}$ & $2.4 \mathrm{hi}$ & 5.1 & & $12.5 \mathrm{~g}$ & $10.0 p$ & 22.5 & & $0.3 \mathrm{i}$ & \\
\hline Check (Healthy) & & $10.1 \mathrm{c}$ & $4.1 \mathrm{~b} \propto d$ & 14.2 & 178.4 & 30.5 de & $18.2 \mathrm{~b}$ - & 48.7 & 116.4 & $1.4 \mathrm{~b}$ & 366.7 \\
\hline
\end{tabular}

Egypt. J. Agronematol., Vol. 14, No. 1, (2015) 


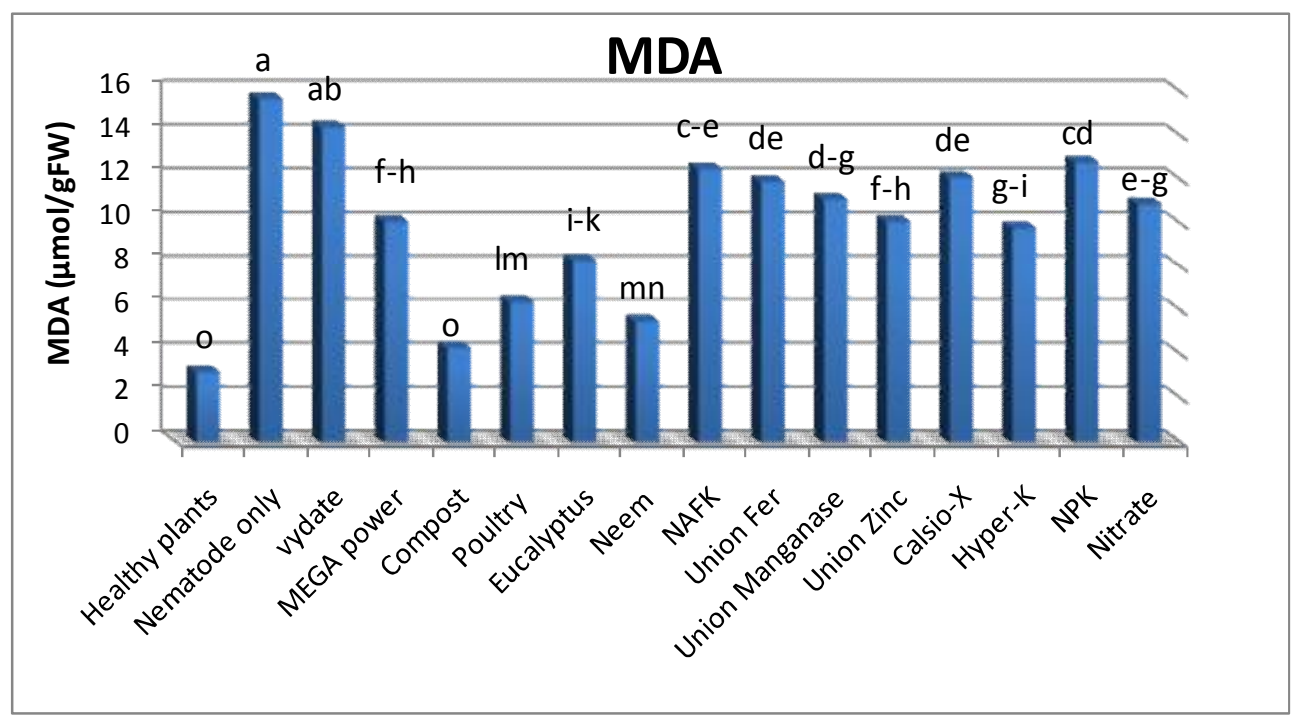

Fig.(1): Changes in MDA in roots of eggplant infected with $M$. incognita and treated with organic and inorganic fertilizers.

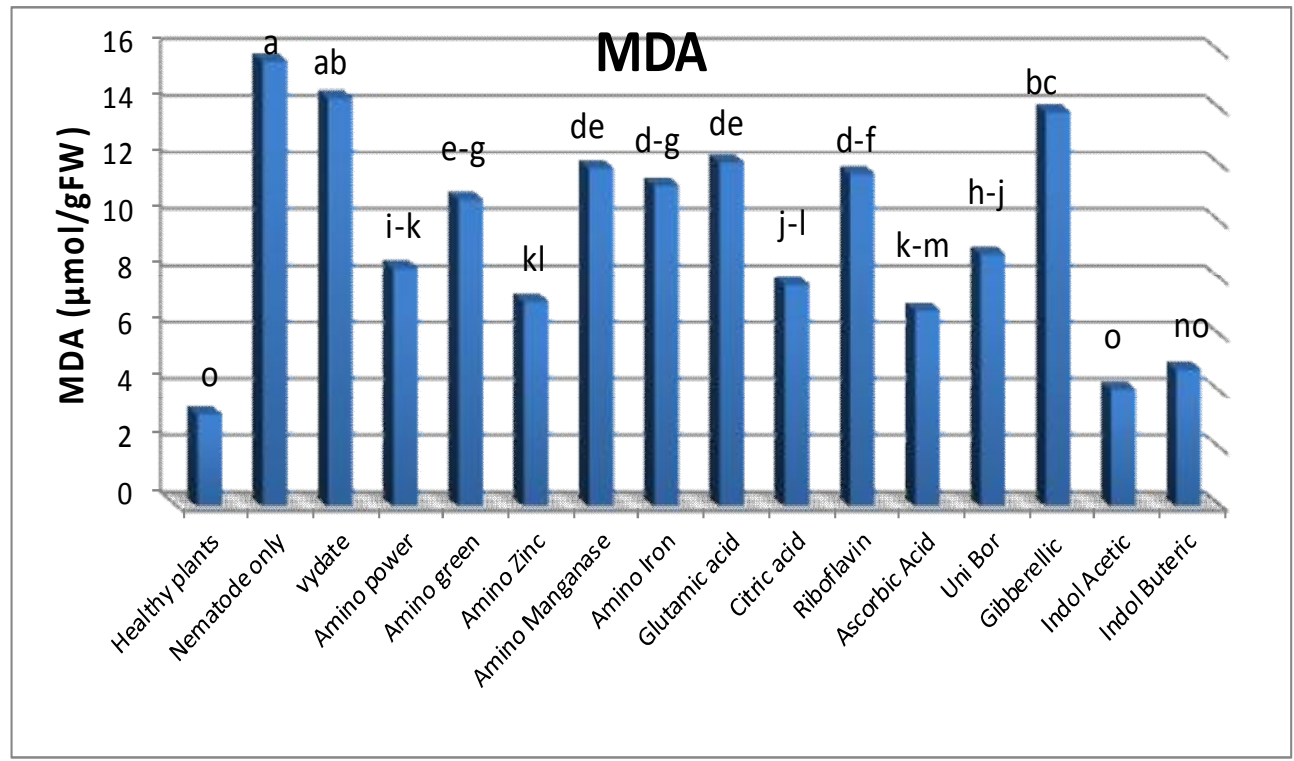

${ }^{*}$ In both Figs, similar letter(s) means insignificant differences.

Fig. (2): Changes in MDA in roots of eggplant infected with M.incognita and treated with some resistance inducers 


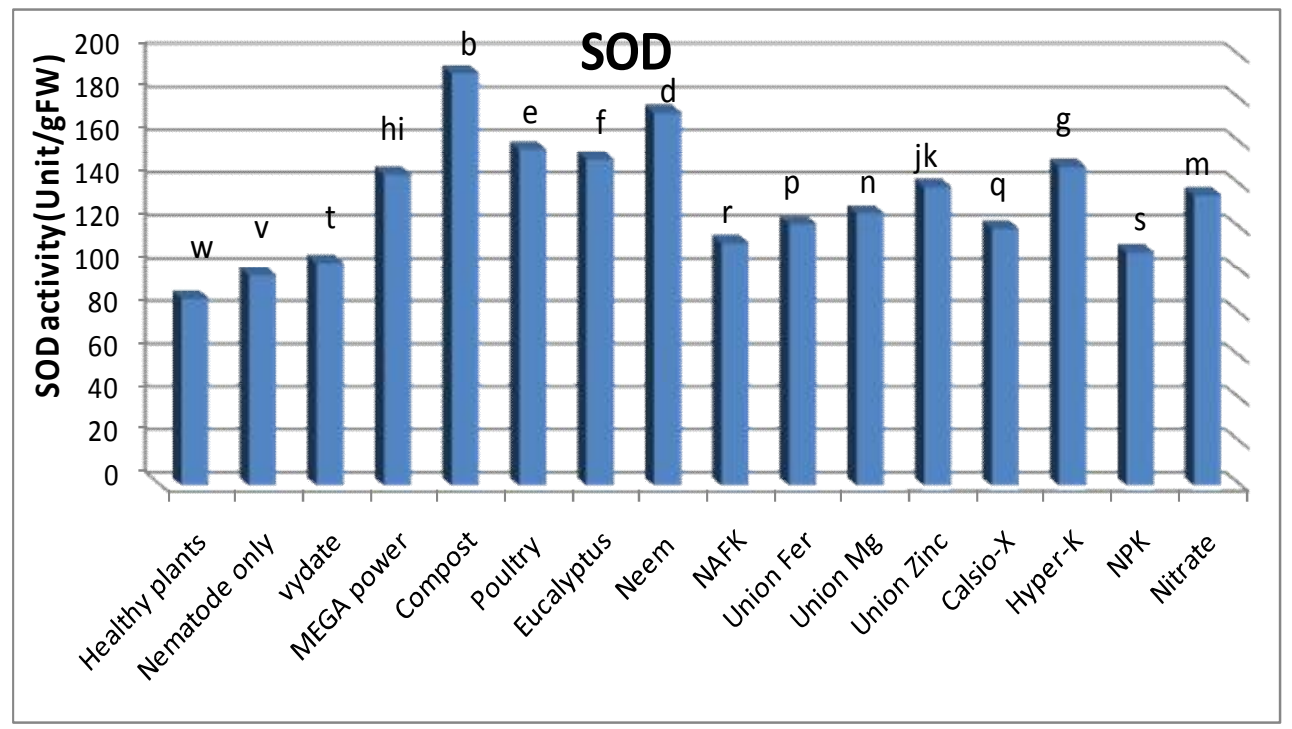

Fig. (3): Changes in the activity of SOD in roots of eggplant infected with M.incognita and treated with organic and inorganic fertilizers.

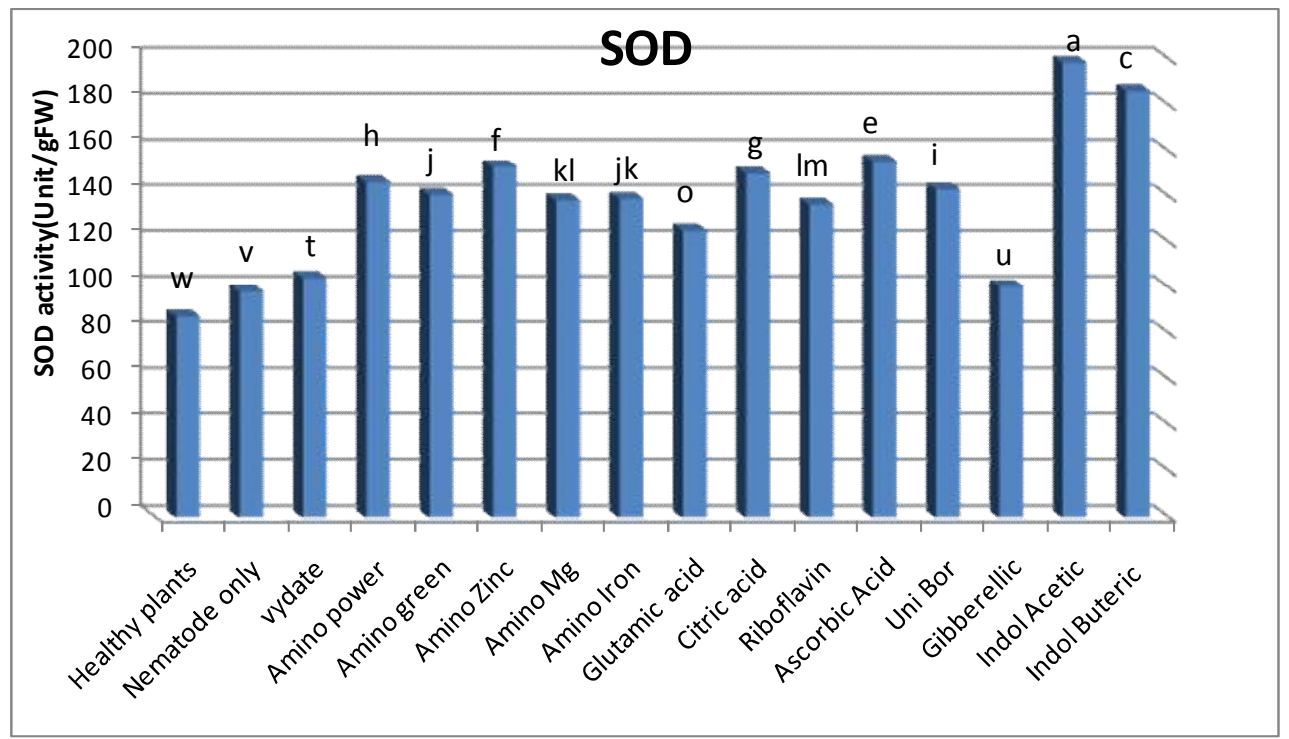

*In both Figs, similar letter(s) means insignificant differences.

Fig.(4): Changes in the activity of SOD in roots of eggplant infected with M.incognita and treated with some resistance inducers. 


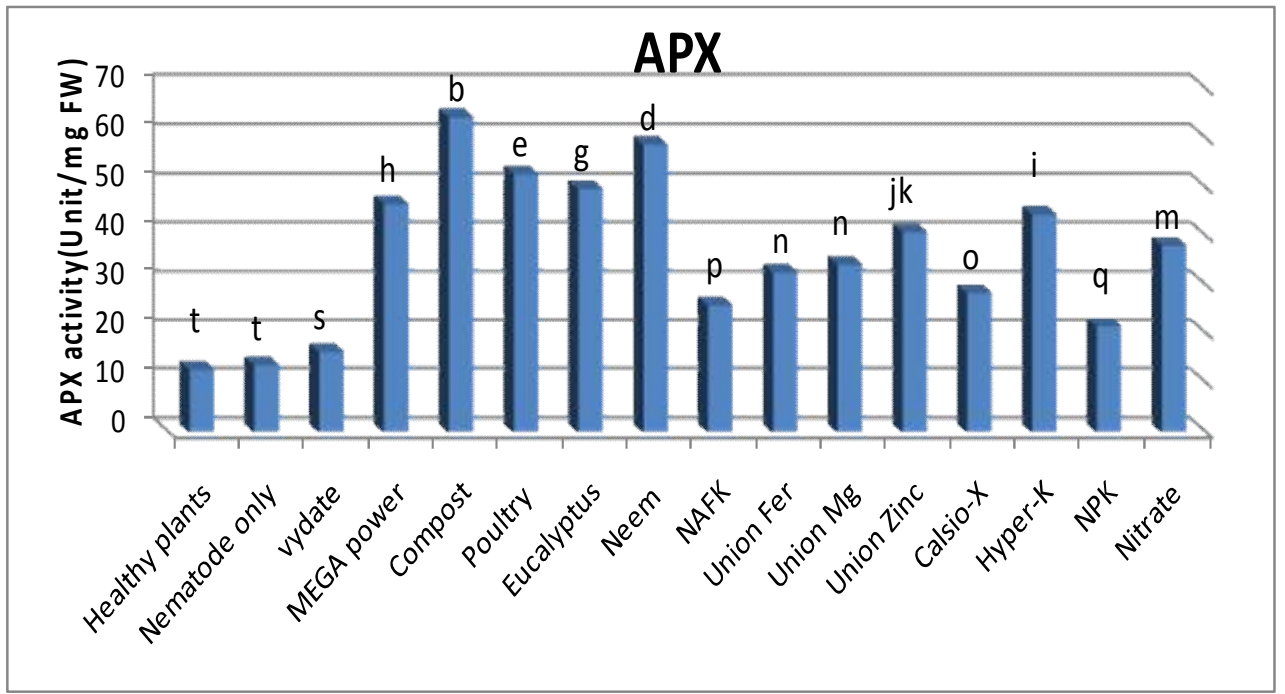

Fig. (5): Changes in the activity of APX in roots of eggplant infected with M.incognita and treated with organic and inorganic fertilizers.

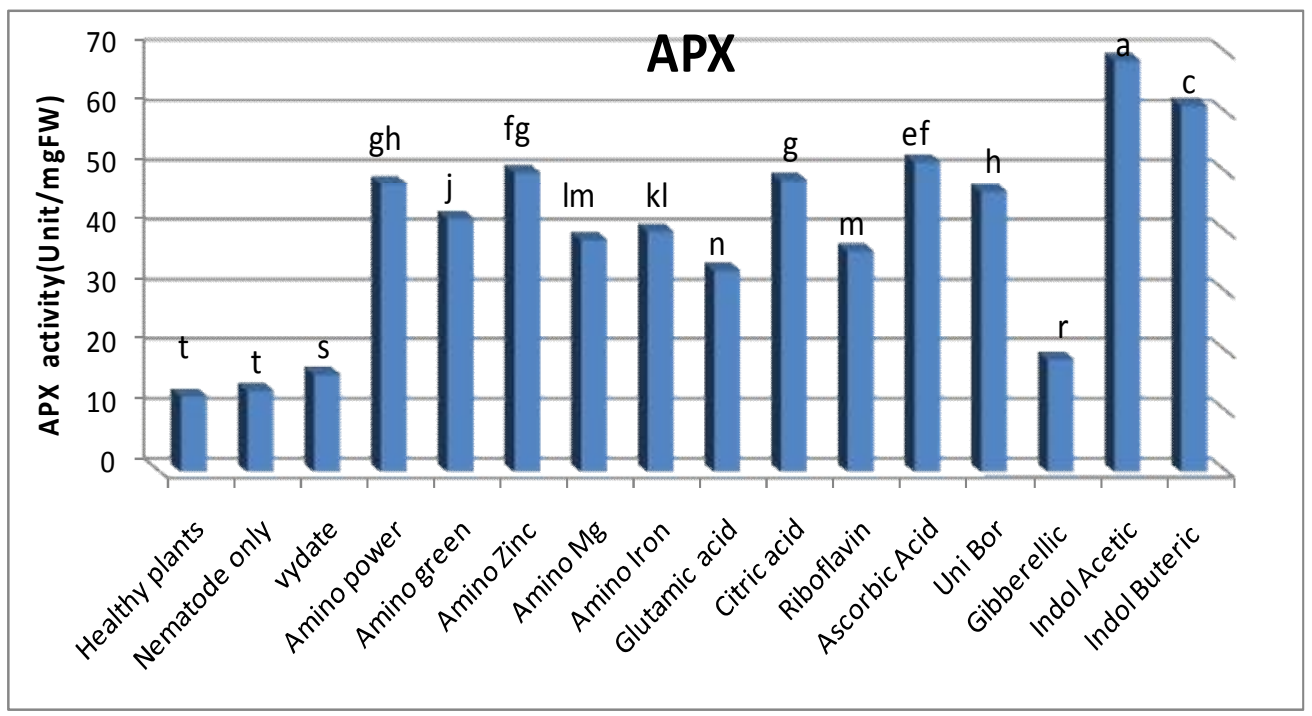

${ }^{*}$ In both figs, similar letter(s) means insignificant differences.

Fig. (6): Changes in the activity of APX in roots of eggplant infected with M.incognita and treated with some resistance inducers. 


\section{Discussion}

Data of the present study show that organic fertilizers are significantly better than commercial inorganic fertilizers in reducing the root-knot nematode counts in soil and on eggplant and improving the growth of treated plants which agreed with the findings of Siddiquiet al. (2001). Compost achieved the best results followed by neem dry leaves, poultry droppings and then eucalyptus dry leaves. Such efficiency may partially due to direct toxic effect of the substances produced during the degradation of the organic matter; and to the role of these substances in helping the treated plants to acquire some resistance against invading nematodes. Compost surpassed all the tested materials in improving growth of the treated plants infected with the root-knot nematode. Substances produced during the degradation of organic matter include volatile fatty acids and organic acids (Kesba and AlShalaby, 2008 and Abd El-Rahman et al., 2008). Nitrogenous compounds, phenols, hydrogen sulfide are also, generated from organic materials with low $\mathrm{C} / \mathrm{N}$ ratio in soil (Riegal and Noe, 2000, and Oka et al., 2007). Furthermore, the indirect effect is related to the role of organic matter in supplying and encouraging microorganisms where many of which exhibits some antagonistic action against nematodes either as direct parasites or by their metabolites produced during their activities (Mankau, 1963).

The nematicidal action of neem formulations is not only due to the compounds present within the neem product, namely, nimbidin and thionimone but also due to other byproducts such as ammonia, formaldehyde, phenols and fatty acids produced during decomposition of neem formulations (Khan et al., 1974). Also, it have been stated that essential oils produced during the degradation of different parts of eucalyptus are responsible for diminishing nematode populations (Dawaret al., 2007 and Moreira, et al., 2009).

Many reports in literature agreed with the findings in the present study and illustrate the role of compost (Rashadet al., 2010 and Zakariaet al., 2013), chicken manure (Karmaniet al., 2011 and Abolusoro and Abolusoro, 2012), neem(Javedet al., 2007 and Farahatet al., 2012) and eucalyptus (Moreira et al., 2009) in reducing nematode populations in soil and on roots as well as improving the growth of the infected plants.

Concerning the commercial inorganic fertilizers, data in the present study show that, hyper $\mathrm{K}^{\circledR}$ followed by union zinc ${ }^{\circledR}$ were significantly the best in reducing the number of galls, root and soil population of $M$. incognita on eggplant. NAFK ${ }^{\circledR}$, Union Fer ${ }^{\circledR}$, Union manganese ${ }^{\circledR}$, Calsio $\mathrm{X}^{\circledR}, \mathrm{NPK}^{\circledR}$ and ammonium nitrate came statistically in the second category. No significant differences were observed between the two tested doses in the majority of cases. Hyper $\mathrm{K}^{\circledR}$ is a commercial product containing $66 \%$ potassium. Potassium sulphate $\left(\mathrm{SO}_{4} \mathrm{KNO}_{3}\right)$ reduced the population density of $M$. incognita in soil and on roots of cowpea (Ahmed et al., 1991). 
Union zinc ${ }^{\circledR}$ is a commercial product containing $12 \%$ chelated zinc by organic and amino acids. Absence of zinc increased nematode density in soil and reduced plant growth (Haque and Mukhopadhyaya, 1975 and Siddiqueet al., 2002). The involvement of minerals especially $\mathrm{Fe}, \mathrm{Mg}, \mathrm{Zn}$ and $\mathrm{Ca}$ in the formation of enzymes (Graham et al., 1988 and Auld, 2001), may explain their role in the acquired systemic resistance by increasing the antioxidant enzymes included in the defense mechanisms which resulted in reducing nematode populations.

NPK $^{\circledR}$ NAFK $^{\circledR}$, Union Fer ${ }^{\circledR}$, Union manganese ${ }^{\circledR}$, Calsio $X^{\circledR}$, ammonium nitrate came after hyper $\mathrm{K}$ and union $\mathrm{Zn}$ in reducing the root-knot counts in soil and on eggplant roots and improving the growth of treated plants. Many reports in literature are in accordance with our findings concerning NPK (Coyne et al., 2004; Farahat, et al., 2010 and Al-Hazmi and Dawaba,2014). The role of $\mathrm{Mn}, \mathrm{Fe}, \mathrm{Ca}$ in hindering nematode reproduction had also been documented by Coyne et al. (2004) and Kheiret al. (2009). Organic and amino acids presented in the tested inorganic fertilizers may affect the reproduction of nematodes on treated host plants and eliminate their biological activities (Al-Sayed and Thomason, 1988; Oka and Cohen, 2001; Abd El-Rahmanet al., 2008 and AmdadulHoqueet al., 2013).

The biocidal mode of action of ammonia is not clear, but several mechanisms are thought to be involved: cell membrane disruption (Rush and Lyda, 1982), elimination of protein gradients across membranes (Docherty and Snider, 1991), and exhaustion of the chemical energy of the cells removing cytosolic ammonia against a concentration gradient (Brittoet al., 2001).

Concerning the organic, amino acid-containing commercial products and plant growth regulators, data in the present study signified that all the tested materials significantly reduced the root-knot nematode counts in soil and on roots of eggplant. Indole acetic and indole butyric acids preceded all the tested materials including organic amendments in enhancing the resistance of treated plants and performing the lowest numbers of nematode counts. Ascorbic acid, amino zinc and citric acid were statistically ranked in the second category.

Growth regulators play an important role in the mechanism of gall formation in Meloidogyne infections. Changes caused by nematode species in cells of a susceptible host are similar to those caused by exogenous indole acetic acid, that is, hypertrophy, hyperplasia, adventitious roots, nuclear division without cell division and break down of the cell wall. Two possible sources of indole compounds in the root galls have been suggested. First, nematodes inject through their saliva the enzymes glycosidase and protease into the host cells and release free auxins from the complexes in the host. The proteases breaking down proteins to amino acids including tryptophan, the IAA precursor, and also acids such as phenylalanine, alanine, histidine and serine which promote auxinsynthysis. The second possibly is that the nematode itself releases auxins during feeding. Perhaps indole compounds 
are formed in nematodes as end products of metabolism and are exerted by endoparasites into plant tissue or by ectoparasites into the root region. IAA have been detected in larvae and egg masses of Meloidogyne species (Decker, 1981).

Successful host-parasite relationship relies on the formation of feeding sites which depends mainly on the availability of some amino acids and plant auxins at specific concentrations (Khanna and Yadav, 2004). Accordingly, any disturbance in such concentrations may restrict the activities of nematode biology which shows sings of resistance. From this point of view, such disturbance may result from the exogenous application of indole IAA or IBA as well as amino acid-containing formulations which ultimately aquire some resistance to the treated eggplant against the root-knot nematode. These findings are in accordance with those of $\mathrm{Yu}$ and Zhena (2007). They reported that IAA stimulated catalase, peroxidase and polyphenol oxidase activities in pear fruits, indicating that IAA can induce fruitmediated resistance against pear fruit diseases although it had no direct antifungal activity. Both indoles (IAA and IBA) are considered pesticide derivatives (Omar and Muneer, 2005) and IBA is registered by EPA (1992) as a biocontrol pesticide with the PC Code 046701 . They reported that IBA has been classified as a biocontrol pesticide because it is similar in structure and function to the naturally-occurring plant growth indole-3-acetic acid.

In the present study, ascorbic acid came after IAA, IBA in reducing the rootknot nematode counts in soil and on roots of eggplant. Ascorbic acid, in the present results is considered a very good resistance inducer against this nematode. Our findings agreed with those of Arrigoniet al., 1979 when they found that artificial increase in ascorbic acid concentration transforms susceptible plants into resistant ones. These results also agreed with those of Hamada et al. (2000) and Moawad (2005). They reported that ascorbic acid was effective in reducing stresses of the root-knot nematodes on their hosts.

Our results proved that all the tested amino acids and organic acidscontaining commercial products significantly reduced the counts of $M$. incognitaon eggplant with superiority of amino zinc, followed by amino power and amino green. These results agreed with those in literature illustrating the role of amino acids in diminishing nematode populations and inducing resistance in treated plants (Oka and Cohen, 2001; Kesba, 2003, Saeed, 2005 and AmdabulHoqueet al., 2013). The superiority of amino zinc (a commercial product containing organic and amino acids and $10 \%$ zinc) may be due to the effect of both amino and organic acids as well as zinc.

The formation of reactive oxygen species (ROS) is the most common defense mechanism in which lipid peroxidation (accounting for cell death after nematode invasion) is induced (Montes et al., 2004 and Bakker, et al., 2006). Hence, increasing the rates of MDA and $\mathrm{H}_{2} \mathrm{O}_{2}$ in different hosts in response to 
infection with $M$. incognita, in the present study as compared to healthy plants accounted for the defense mechanism against nematode invasion. Our results agreed with those of Davis et al. (2000) and Huang et al. (2004) who stated that the initial reaction of the susceptible cultivars is similar to that of resistant hosts and may be resulted from nematode secretions into plant tissues.

Increase in superoxide dismutase (SOD) and peroxidase activity results to be an adaptive response which provides the plant with protection against biotic and abiotic stress (Guidaet al., 1992). The protective activity of SOD, and catalase (CAT) was enhanced in susceptible plants but decreased in resistant ones (Zacheoet al., 1983). Superoxide dismutase prevents the deleterious effect of $\mathrm{O}_{2}$ radicals in root cells and transform it to $\mathrm{H}_{2} \mathrm{O}_{2}$ which is then transformed by catalase to harmless $\mathrm{O}_{2}+\mathrm{H}_{2} \mathrm{O}$. Accordingly, in susceptible tomato roots infected with $M$. incognita,SOD activity was considerably increased in comparison to uninfected controls and decreased in resistant cultivars (Zacheoet al., 1987 and Sgherriet al., 2013). These findings are in accordance with our results whereas superoxide dismutase (SOD), ascorbate oxidase (APX) were significantly higher in treated plants.

Systemic acquired resistance can be enhanced by applying materials of different sources which, in many cases, suppress nematode populations and improve the growth of treated plants either directly by their effects on nematodes or by enhancing resistance of treated plants.

\section{References}

Abd El-Rahman, Fawzia H.; Clark, S.andSaleh, M. A. (2008). Natural organic compounds as alternative to methyl bromide for nematodes control. Journal of Environmental Science and Health, Part B, 43: 680-685.

Abolusoro, S.A. and Abolusoro, P.F. (2012). Effects of organic manure types on the growth, yield as well as root and soil populations of root-knot nematodes (Meloidogyne incognita) of tomato. Scientific Journal of Agriculture, 1(5): 138-144

Ahmed, S. S.; Kandil, M. M. and Al-Ansi, N. A. (1991).Effect of some fertilizers on development of Meloidogyne incognita and growth of cowpea. Annals of Agric. Sci. Moshtohor, 29 (3):1215-1220.

Al-Hazmi, A.S. and Dawaba, A.M.A. (2014). Effect of urea and Certain NPK fertilizers on cereal cyst nematode (Heteroderaavenae) on wheat. Saudi Journal of Biological Sciences, 21: 191-196.

Al-Sayed, A.A. and Thomason, D.J. (1988). Meloidogyne incognita and tomato response to thiamine, ascorbic acid, L-arginine and L-glutamic acid. Journal of Nematology, 20 (3): 451-456. 
AmdadulHoque, A.K.M.; Bhuiyan, Md. R.; Khan, M.A.I.; Mahmud, A. and Ahmed, M.U. (2013).Effect of amino acids on root-knot nematode (Meloidogynejavanica) infecting tomato plant. Archives of Phytopathology and Plant Protection, 10: 1080.

Arrigoni, O.; Zacheo, G.; Arrigoni-Liso, R.; Bleve-Zacheo, T. and Lamberti, F. (1979). Relationship between ascorbic acid and resistance in tomato plants to Meloidogyne incognita. Phytopathology, 69: 570-581.

Aryal, S. K.; Davis, R.F.; Stevenson, K.L.; Timper, P. and Ji, P. (2011). Influence of infection of cotton by Rotylenchulusreniformis and Meloidogyne incognita on enzymes involved in systemic acquired resistance. Journal of Nematology, 43(3-4): 152-159.

Auld, D.S. (2001). Zinc coordination share in biochemical zinc sites. Biometals, 14: 271-313.

Bakker, E., Dees, R., Bakker, J., Goverse, A. (2006). Mechanisms involved in plant resistance to nematodes. In Tuzen, S, Bent, E(eds) Multigenic and Induced Systemic Resistance in Plants. New York Springer Sci. pp. 314344.

Baldacci-Cresp, F.; Chang, C.; Maucourt, M.; Deborde, C.;Hopkins, J.; Lecomte, P.; Bernillon, S.;Brouquisse, R.; Moing, A.; Abad, P.; Herouart, D.; Puppo, A.; Favery, B and Frendo, P. (2012). (Homo) glotathine deficiency impairs root-knot nematode development in Medicagotruncatula.Plos Pathogen, 8(1): 1-12.

Beauchamp, C. and Fridovich, I. (1971). Superoxide dismutase: improved assays and assay applicable to acrylamide gels. Anal.Biochem., 44:276-287.

Britto, D.T.; Siddiqi, M.Y.; Glass, A.D.M. and Kronzuker, H.J. (2001). Futile transmembrane $\mathrm{NH} 4+$ cycling: a cellular hypothesis to explain ammonium toxicity in plants. Proc. Natl. Acad. Sci. U.S.A. 98:4255-4258.

Chinnasri, B.; Sipes, B.S. and Schmitt, D.P. (2006). Effects of inducers of systemic acquired resistance on reproduction of Meloidogynejavanica and Rotylenculusreniformis in pineapple. Journal of Nematology, 38(3): 319325.

Coyne, D. L.; Sahrawat, K. L. and Plowright, R.A. (2004).The influence of mineral fertilizer application and plant nutrition on plant-parasitic nematodes in upland and lowland rice in côted'ivoire and its implications in long term agricultural research trials. Expl. Agric., 40: 245-256.

Davis, E. L.; Hussey, R. S.; baum, T.J.; Bakker, J.; Schots, A.; Rosso, M.N. and Abad, P. (2000). Nematode parasitism genes. Annual Review of Phytopathology, 38:365-396. 
Dawar, S; Sumaira, M.; Y. and Zaki, M.J. (2007). Use of Eucalyptus sp., in the control of Meloidogynejavanica root-knot nematode. Pakistan J. Bot., 39(6): $2209-2214$.

Decker, H. (1981).Plant Nematodes and their Control: Phytonematology. Amerind Publishing Co. Put. Ltd, New Delhi.543 pp.

Docherty, P.A. and Snider, M.D. (1991).Effect of hypertonic and sodium-free medium on mammalian cells. Physiol. 146: 34-42.

El-Beltagi, H.S.; Farahat, A.A.; Al-Sayed, A.A. and Mahfoud, N.A. (2012). Response of Antioxidant substances and enzyme activities as a defense mechanism against root-knot nematode infection.Not. Sci. Horti. Agrobo, 40(1): 132-142.

EPA, Environmental Protection Agency (1992).R.E.D. Facts, Indole-butyric Acid.EPA-738-F-92-001, August 1992

Farahat, A.A. (1989). Concentration and method of application of some plant growth substances in relation to tomato growth and infectivity with the rootknot nematodes, Meloidogyne spp. Annals of Agric. Sci., Moshtohor, 27(3): 1853-1858.

Farahat, A.A.; Al-Sayed, A.A.; El-Beltagi, H.S. and Mahfoud.N.M.(2012). Impact of organic and inorganic fertilizers on nematode reproduction and biochemical alterations on tomato. Not. Sci. Biol., 4(1): 48-55.

Farahat, A.A.; Al-Sayed, A.A. and Mahfoud, N.A. (2010). Compost and other organic fertilizers in the scope of root-knot nematode reproduction and control. Egyptian Journal of Agronematology, 9(1): 18-19.

Graham, R.D.; Hannam, R.J. and Vern, N.C. (1988). Manganese in Soils and Plants. Development in Plant and Soil Sciences Volume 33: 125-137.

Giebel, J. (1982). Mechanism of resistance to plant nematodes. Annu. Rev. Phytopathology, 20: 257-279.

Goody, J.B. (1957). Laboratory methods for work with plant and soil nematodes. Bulten No. 2. Ministry of Agriculture, London, pp. 47.

Guida, G.; Zacheo, G and Bleve-Zacheo, T. (1992). Activation of detoxifying enzymes in tomato roots following paraquat treatment and nematode infection. NematologicaMediterranea, (20): 203-209.

Hamada, A.M.; El-Zawahry, A.M. and Al-Hakimi, A.M. (2000). Soaking of eggplant in ascorbic acid, pyridoxine or thiamine for control of Meloidogynejavanica infection. Assiut Journal Agric. Sci., 31(3): 227-241.

Haque, M.S. and Mukhopadhyaya, M.C. (1975). Influence of some micronutrients onRotylenchulusreniformis. Indian Journal of Nematology, 5: 77-78. 
Heath, R. L. and Packer, L. (1968). Photoperoxidation in isolated chloroplasts. I. Kinetics and stoichiometry of fatty acid peroxidation. Arch. Biochem. Biophys., 125:189-198.

Hodges, D. M.; DeLong, J. M.; Forney, C. F. and Prange, R. K. (1999).Improving the thiobarbuturic acid-reactive-substances assay for estimating lipid peroxidation in plant tissues containing anthocyanin and other interfering compounds. Planta, (207) 604-611.

Huang, G.; Dong, R.; Maier, T.; Allen, R.; Davis, E. L.; Baum, T. J. and Hussey, R.S. (2004).Use of solid-phase subttactive hybridization for the identification of parasitism gene candidates from the root-knot nematode Meloidogyne incognita. Molecular Plant Pathology, 5:217-222.

Javed, N.; Gowena, S.R.; Inam-ul-Haqa, M. and Anwarb, S.A. (2007). Protective and curative effect of neem (Azadirachtaindica) formulations on the development of root-knot nematode Meloidogynejavanica in roots of tomato plants. Crop Protection 26: 530-534.

Kaplan, D. T. and Keen, N. T. (1980). Mechanisms conferring plant incompatibility to nematodes. Revue de Nematologica, 3:123-134.

Karmani, B. K.; Jiskani1, M. M.; Khaskheli, M. I. and K. H.Wagan (2011). Influence of organic amendments on population and reproduction of root knot nematode, Meloidogyne incognita in eggplants. Pak. J. Agri., Agril. Engg., Vet. Sci., 27 (2): 150-159.

Kesba, H. H. (2003). Integrated nematode management on grapes grown in sandiness soil. Ph.D. Thesis. Fac. of Agric., Cairo Univ., pp.189.

Kesba, H. H. and El-Beltagy, H.E.S. (2012). Biochemical changes in grape rootstocks resulted from humic acid treatments in relation to nematode infection. Asian Pacific Journal of Tropical Biomedicine (2012): 287-293.

Kesba, H. H. and Al-Shalaby, Mona, E. (2008).Survival and reproduction of Meloidogyne incognita on tomato as affected by humic acid. Nematology, 10(2): 243-249.

Khan, A.M., Alam, M.M., Ahmad, R., (1974). Mechanism of the control of plant parasitic nematodes as a result of the application of oil cakes to the soil. Indian Journal of Nematology, 4: 93-96.

Khanna, D.R. and Yadav, P.R. (2004). Biology of Helminthes.Discovery Publishing Hose, 4831/24, Ansari Road, Darya Gani, New Delhi 110002 (India), pp 444. 
Kheir, A. M.; Al-Sayed, A. A. and Saeed, M. R. (2009). Suppressive effects of inorganic fertilizers on $M$. incognita infecting soybean. Egyptian Journal of Agronematology, 7(1): 9-19.

Mankau, R. (1963). The effect of some organic additives upon soil nematode populations and associated natural enemies. NematologicaMediterranea, 7: 65-73.

Moawad, M. M. (2005). Studies on nematode pests associated with some oil crops and their control methods. Ph. D. Thesis. Fac. of Agric., Al-Azhar Univ., pp.82.

Montes, M. J.; Lopez-Brana, I. and Delibes, A. (2004). Root enzyme activities associated with resistance to Heteroderaavenaecoferred by gene $\mathrm{Cre} 7$ in wheat, Aegilopstriuncialisintrogression line. Journal of Plant Physiology, 161: 493-495.

Moreira, F.J.C.; Santos, C.D.G. and Innecco, R. (2009). Hatching and mortality of second-stage juveniles of Meloidogyne incognita race 2 in essential plant oils. RevistaCiênciaAgronômica, 40(3): 441-448.

Nakano, Y. and Asada, K. (1981). Hydrogen peroxide is scavenged by ascorbate specific peroxidase in spinach chloroplasts. Plant Cell Physiol., 22:867-880

Oka, Y.and Cohen, Y. (2001).Induced resistance to cyst and root-knot nematodes in cereals by DI-beta-amino-n-butyric acid.Euro. J. Plant Pathology, 107 (2): 219-227.

Oka, Y.; Tkachi, N.; Shuker, S. and Yerumiyahu, U. (2007). Enhanced nematicidal activity of organic and inorganic ammonia-releasing amendments using neem extracts. Journal of Nematology, 39, 9-16.

Omar, M. and Muneer, M. (2005).Comparative photocatalytic study of two selected pesticide derivatives, Inole-3-acetic acid and Indole-3-buteric acid in aqeous suspensions of titanium dioxide. Journal of Hazard Mater, 11(1-3): 219-227.

Rashad, Ferial, M.; Saleh, W.D. andMoselhy, M.M. (2010). Bioconversion of rice straw and certain agro-industrialwastes to amendments for organic farming systems.l-composting, quality, stability and maturity indcies. Bioresource Technology, 101: 5951-5960.

Riegel, C. and Noe, J.P. (2000). Chicken litter soil amendment effects on soilborne microbes and Meloidogyne incognita on cotton. Plant Disease, 84: 12751281.

Rush, C.M. and Lyda, S.D. (1982).Effects of anhydrousammonia on mycelium and sclerotia of Phymatotrichumomnivorum. Phytopathology, 72: 1085-1089.

Saeed, M.R.M. (2005). Utilization of some specific materials to stimulate resistance 
in some host plants against the root-knot nematodes. Ph. D. Thesis. Cairo Univ. Fac. of Agric., pp.220.

Sgherri, C.; Ranieri, A. and Quartacci M. F. (2013). Antioxidative responses in Vitisvinifera infected by grapevine fanleaf virus. Journal of Plant Physiology, 170: $121-128$.

Siahpoush, S.; Sahebani, N. and Aminian, H. (2011). Change of some defense compounds of cucumber treated with Bacillus cereus and salicylic acid against Meloidogynejavanica. African J. of Plant Sci., 5(14): 829-834.

Siddiqui, Z. A.; Iqbal, A.; Mahmood, I. (2001). Effects of Pseudomonas fluorescensand fertilizers on the reproduction of Meloidogyne incognita and growth of tomato. Applied Soil Ecology, 16: 179-185

Siddiqui, I.A.; Shaukat, S.S.And Hamid, M. (2002).Role of zinc in rhizobacteriamediated suppression of root-infecting fungi and root-knot nematode. Journal of Phytopathology, 150: 569-575.

Sticher, L.; Mauch-Mani, B. and Metrarux, J.P. (1997). Systemic acquired resistance. Annual Review of Phytopathology, 35: 235-270.

Taylor, A.A; Dropkin, V. H. and Martin, G. C. (1955).Perineal pattern of root- knot nematodes. Phytopathology, (45):26-30.

Yu, T.andZhena, X.D. (2007).Indole-3-acetic acid enhances the biocontrol of Penicilliumexpansumand Botrytis cinerea on pear fruit by Cryptococcus laurenti. FEMS Yeast Research 7(3): 459-464.

Zacheo, G.; Arrigoni-Liso, R.; Bleve-Zacheo, T.; Lamberti, F. and Arrigoni, O. (1983). Mitochondria peroxidase and superoxide dismutase activities during the infection by Meloidogyne incognita of susceptible and resistant tomato plants. NematologicaMediterranea, 11(2):107-114.

Zacheo, G.; Bleve-Zacheo, T.; Pricolo, G. and Zacheo, T.B. (1987).Metabolic changes in enzyme levels in potato roots infested by potato-cyst nematode, Globoderapallida (Pa3) and Globoderarostochiensis (R01). NematologicaMediterranea, 15(2):293-302.

Zakaria, Hanan M.; Kassab, A.S.; Shamseldean, M.M.; Oraby, Mona M. and EIMourshedy, M.M.F. (2013). Controlling the root-knot nematode, Meloidogyne incognita in cucumber plants using some soil bioagents and some amendments under simulated field conditions. Annals of Agricultural Science, 58: 77-82. 


\section{إكساب الباذنجان صفة المقاومة لنيماتودا تعقد الجذور}

\section{باستخدام الأسمدة العضوية وغير العضوية وبعض المنتجات التجارية} التي تحتوي على الأحماض الأمينية ومنظمات النمو
أحمد عبد السلام فرحات*، السيد أبو المعاطي السيد*، عبد المنعم محمد رضوان عفيفي***،

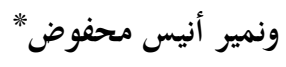

*قسم الحيوان والنيماتولوجيا الزراعية، *قسم الكيمياء الحيوية - كلية الزراعة - جامعة القاهرة

تم في هذا البحث اختبار قدرة بعض الأسمدة العضوية والغير عضوية والعديد من المنتجات

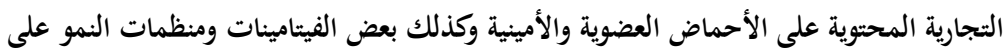

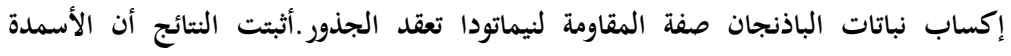

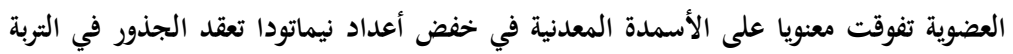

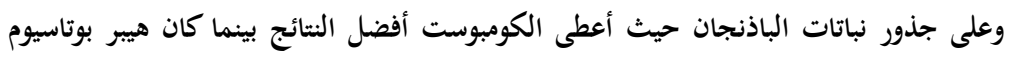

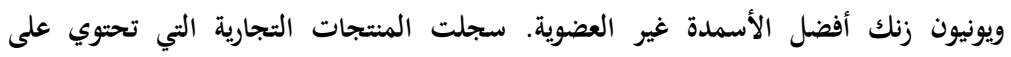

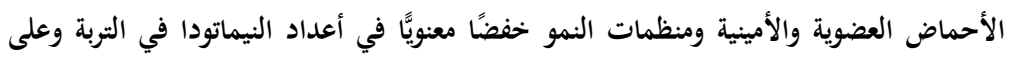
جذور الباذنجان حيث تفوق اندول حمض الخليكواندول حمض البيوتيريك على كل المنتجات

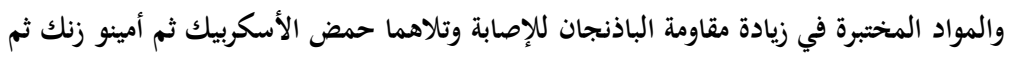

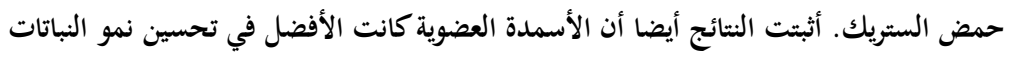

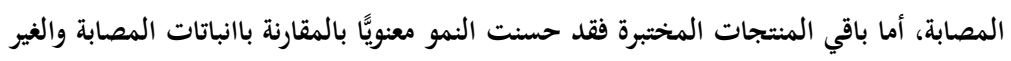

معاملة وحقق اندول حمض الخليكواندول حمض البيوتيريك وحمض الستريك أفضل النتائج. كان نشاط انزيم البيروكسيداز عند أقل مستوى له في النباتات السليمة بينما بلغ الذروة في

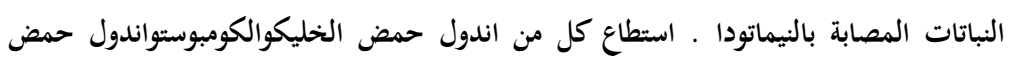

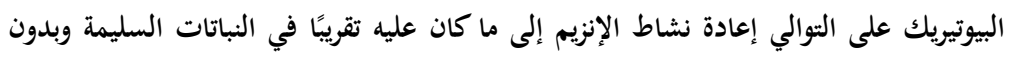

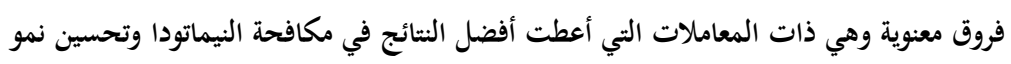

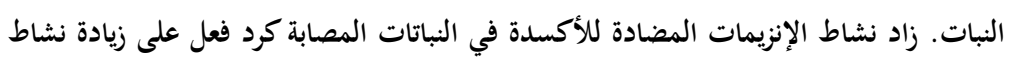

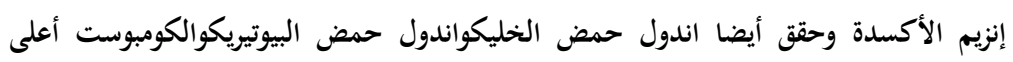

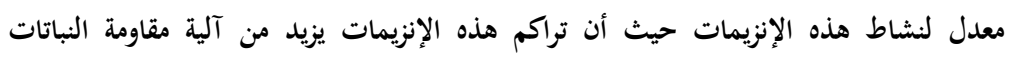
للإصابة بالنيماتودا. 